\title{
Aid on Demand: African Leaders and the Geography of China's Foreign Assistance
}

\author{
Axel Dreher, Andreas Fuchs, Roland Hodler, Bradley C. Parks, \\ Paul A. Raschky, and Michael J. Tierney*
}

March 30, 2015

\begin{abstract}
This article investigates whether the political leaders of aid-receiving countries use foreign aid inflows to further their own political or personal interests. Aid allocation biased by leaders' selfish interests arguably reduces the effectiveness of aid, negatively affecting development outcomes. We examine whether more Chinese aid is allocated to the political leaders' birth regions and regions populated by the ethnic group to which the leader belongs, controlling for objective indicators of need. We have collected data on 117 African leaders' birthplaces and ethnic groups and geocoded 1,955 Chinese development finance projects across 3,545 physical locations in Africa over the 2000-2012 period. The results from various fixed-effects regressions show that current political leaders' birth regions receive substantially larger financial flows from China than other regions. When we replicate the analysis for the World Bank, our regressions with region fixed effects show no evidence of favoritism. Once we control for region fixed effects, we do not find evidence that African leaders direct aid to areas populated by groups who share their ethnicity, for Chinese and World Bank aid alike.
\end{abstract}

*Dreher: Alfred-Weber-Institute for Economics, Heidelberg University; KOF Swiss Economic Institute; CEPR; Georg-August University Goettingen; IZA; and CESifo; email: mail@axel-dreher.de. Fuchs: Alfred-Weber-Institute for Economics, Heidelberg University; email: mail@andreas-fuchs.net. Hodler: Department of Economics and SIAW-HSG, University of St.Gallen; OxCarre, University of Oxford; and CESifo; email: roland.hodler@unisg.ch. Raschky: Department of Economics, Monash University; email: Paul.Raschky@monash.edu.au. Parks: Institute for the Theory and Practice of International Relations, The College of William and Mary; email: bcpark@wm.edu. Tierney: Department of Government, The College of William and Mary; email: mjtier@wm.edu. 
Keywords: Foreign aid, Favoritism, Aid allocation, Africa, China, Official Development Assistance, Georeferenced data, Spatial analysis

JEL classifications: D73, F35, P33, R11

Acknowledgements: We thank Heiwai Tang, Takaaki Masaki, conference participants at the Convening of the AidData Research Consortium at the College of William \& Mary in Williamsburg, Virginia (January 2014) and the Annual Conference of the International Political Economy Society in Washington, DC (November 2014), as well as seminar audiences at the European Bank for Reconstruction and Development in London (October 2014), NHH Bergen, the University of Bergen, KOF Zurich (November 2014), Heidelberg University (December 2014), Goethe University Frankfurt (January 2015), University of Sheffield (February 2015), the University of Mannheim, and the ESG Management School (March 2015) for helpful comments. We also thank Humanity United and the Hewlett Foundation for the generous funding that made this research possible. Evelyn Hytopoulos, Scott Stewart, Charles Perla, Harsh Desai, Daniel Lantz, Lauren Su, Catherine Crowley, Faith Savaino, Melanie Gilbert, Torey Beth Jackson, Tiffanie Choi, Rebecca Thorpe, Darice Xue, Jiaorui Jiang, Junrong Zhu, Ze Fu, Zach Baxter, Graeme Cranston Cuebas, Xiao Liu, Emily Qiu, Hanyang Xu, Dylan Kolhoff, Grace Perkins, Yue Zhang, Rohan Desai, Will Nelson, Ryan Septon, Elizabeth Saccoccia, Rachel Benavides, Dominic Sanzotta, Michael Hathaway, Warren Kirkwood, Connor Kennedy, Laura Preszler, Andrea Soleta, Sara Gomez, Tom Westover, Ann Rogers, Nate Tanner, Rebecca Schectman, Matt Westover, Sara Rock, Jordan Fox, Emily Tanner, Rachel Kellogg, Austin Trotta, Isabel Docampo, Lu Sevier, Joseph Dobbels, Julia Varoutsos, Steven Livingston, Victor Polanco, Emily McLenigan, Bilal Asad, Qi Jiang, Anna Umstead, Lauren Harrison, James Willard, Robert Francis, Justin DeShazor, McKay Corbett, Brittany Tennant, and Dominick Margiotta provided outstanding research assistance. 


\section{Introduction}

Recent visitors to the village of Yoni, located in Bombali district, Sierra Leone, will find "a wonderful school in the middle of what Africans call 'the bush'" (Acemoglu and Robinson 2012). The school was built with Chinese aid, and Yoni is the home town of Sierra Leone's President, Ernest Bai Koroma. A fancy new school in the President's home town could be a simple coincidence. However, several studies on patronage politics show that, under some conditions, government officials systematically favor their home regions (e.g., Barkan and Chege 1989; Moser 2008; Do et al. 2013; Mu and Zhang 2014; Burgess et al. forthcoming). Most notably, Hodler and Raschky (2014a) study favoritism in a large sample of subnational administrative regions from all over the world. They find that the birth region of the current political leader has more intense nighttime light than other regions, suggesting that the government is directing additional resources to those areas. Higher foreign aid inflows and weaker institutions at the recipient-country level amplify this effect. We therefore have good reason to believe that the 'school in the bush' reflects a broader pattern.

In this paper, we investigate whether and to what extent African political leaders use foreign aid to favor their birth regions as well as areas populated by their own ethnic group. ${ }^{1}$ China is well-known for its principle of non-interference in the domestic affairs of recipient countries - a principle that is officially reiterated in the Chinese government's 2014 white paper on foreign aid, which explains that " $[\mathrm{w}]$ hen providing foreign assistance, China adheres to the principles of not imposing any political conditions, not interfering in the internal affairs of the recipient countries and fully respecting their right to independently choose their own paths and models of development" (State Council 2014). Therefore, as previous qualitative research suggests, Chinese aid may be particularly easy to exploit for politicians who are engaged in patronage politics (e.g., Tull 2006; Bräutigam 2009; Mthembu-Salter 2012; Jansson 2013).

We introduce a new georeferenced dataset on the subnational allocation of Chinese development finance projects across Africa over the 2000-2012 period. ${ }^{2}$ We use these data to test whether China's non-interference principle allows African leaders to (ab)use

\footnotetext{
${ }^{1}$ We thereby contribute to the literature on ethnic favoritism, which goes back to Bates (1974). Many recent studies have focused on African political leaders and the role played by their ethnicity in shaping government policy (e.g., Kasara 2007; Franck and Rainer 2012; Kramon and Posner 2012, 2013; De Luca et al. 2015; Burgess et al. forthcoming, Francois et al. forthcoming). For ease of exposition, we will use the term "aid" to refer to all official financing flows (Official Development Assistance and Other Official Flows) and will postpone technical definitions until we reach the empirical part of the paper.

${ }^{2}$ These new data can be used to investigate a number of important questions related to the nature, allocation, and impact of Chinese aid. We make them available at http://china.aiddata.org/.
} 
development projects for patronage politics. Specifically, we study whether Chinese aid is disproportionately allocated to the birth regions of the recipient countries' political leaders, or to regions mainly populated by the leaders' ethnic groups, controlling for a large number of subnational variables and various fixed effects.

Our results show that the political leaders' birthplaces receive larger flows of Chinese official financing. The result is strongest for overall official financing flows, which also include non-concessional loans and grants without development intent, going to regions at the first subnational administrative level (ADM1) like provinces, states, or governorates. In particular, when controlling for country-year and region fixed effects, we find that overall official financing flows almost triple when a region becomes the political leader's birth region. Focusing on a stricter definition of aid that comports with the OECD's definition of Official Development Assistance (ODA) ${ }^{3}$ our fixed-effects regressions still suggest an increase of slightly more than 75 percent to the political leaders' birth regions at the ADM1 level. While there is also some evidence that the number of aid projects and aid funding volumes get larger at the level of second subnational administrative (ADM2) regions, e.g., districts or municipalities, from which the political leader originates, these results are not robust to the inclusion of region-fixed effects and are thus potentially spurious. Moreover, regressions with region-fixed effects provide no evidence that World Bank aid flows disproportionally to the political leaders' birth regions. These findings are consistent with the Chinese government's stated non-interference principle and with World Bank project preparation policies that are designed to target development outcomes and prevent aid from being diverted for personal or domestic political reasons. However, controlled for region fixed effects, we find no evidence that either Chinese or World Bank aid is directed to areas populated by the ethnic group to which political leaders belong.

This paper builds upon and contributes to the empirical literature on aid allocation, which traces its origins to McKinlay and Little (1977). ${ }^{4}$ Dreher et al. (2011) compare some of the so-called "new" donors (excluding China) with the "old," mainly Western donor countries organized in the OECD-DAC. They find that "new" and "old" donors behave

\footnotetext{
${ }^{3}$ The OECD-DAC defines ODA as "[g]rants or loans to [developing] countries and territories [...] and to multilateral agencies which are: (a) undertaken by the official sector; (b) with promotion of economic development and welfare as the main objective; (c) at concessional financial terms (if a loan, having a grant element of at least 25 per cent). In addition to financial flows, technical co-operation is included in aid" (OECD DAC glossary, available at http://www.oecd.org/dac/dac-glossary.htm).

${ }^{4}$ Prominent contributions include Maizels and Nissanke (1984), Alesina and Dollar (2000), Kuziemko and Werker (2006), and Faye and Niehaus (2012). On the World Bank, see Frey and Schneider (1986), Kilby (2009), and Dreher et al. (2009).
} 
similarly, but the "new" ones are less responsible to recipient needs. ${ }^{5}$ Dreher and Fuchs (forthcoming) analyze data on Chinese foreign aid projects at the recipient country-level from various sources and find that - consistent with China's principle of non-interference in internal affairs - Chinese aid is not influenced by the democracy levels or governance characteristics of recipient countries. Contrary to the conventional wisdom, they also find that China's aid allocation is not primarily motivated by a desire to access recipient countries' natural resource endowments. Overall, at the country-level, Chinese aid does not seem to be allocated very differently from Western aid. In contrast, we compare the subnational allocation of aid from China and the World Bank, which allows testing whether the allocation of Chinese aid within recipient countries looks substantially different when compared to that of one of the most important "traditional" donors.

We are not the first to investigate the allocation of foreign aid within countries. However, other contributions that rely on subnationally geocoded aid data typically focus on a single country (e.g., Franken et al. 2012; Nunnenkamp et al. 2012; Dionne et al. 2013; Briggs 2014; Jablonski 2014), or on a cross-section of subnational localities from different countries (e.g., Powell and Findley 2012; Öhler and Nunnenkamp 2014). In this paper, we analyze geocoded data for a large number of recipient countries over a longer period of time. This research design provides significant advantages over previous studies. Focusing exclusively on cross-sectional variation, a positive association between the location of aid projects and the location of a leader's birthplace (or ethnic region) could simply be driven by permanent or highly persistent region-specific characteristics. ${ }^{6}$ Relying on variation within regions over time in tandem with binary indicator variables for the years prior to and after the political leader originates from a certain region allows us to identify potential causal effects of the political leaders' birth (or ethnic) regions on the amount of aid a region receives. The second difference between this paper and previous contributions is our focus on Chinese aid, rather than aid allocated by so-called "traditional" donors.

Understanding the allocation of Chinese aid is not only of interest by and in itself. It may also help to explore the expected impact of Chinese aid. The literature on the effectiveness of aid does not provide clear answers on the relationship between allocation and effectiveness. ${ }^{7}$ However, since previous research on aid's impact relies almost exclusively

\footnotetext{
${ }^{5}$ While the terms "new donor" or "non-traditional donor" are frequently used for donors like China and India, both countries' first aid deliveries took place in the 1950s.

${ }^{6}$ We use the term "region" in this paper to refer to subnational localities, not large geographical groupings of countries.

${ }^{7}$ Recent published studies making serious attempts to address endogeneity and get traction on the link between allocation and effectiveness at the country level include Rajan and Subramanian (2008), Clemens
} 
on data from mainly Western donors represented in the OECD's Development Assistance Committee (DAC) and multilateral organizations, ${ }^{8}$ we know very little about whether Chinese aid is more or less effective than "traditional" aid. China is often accused of using foreign aid to curry favor with political leaders of developing countries rather than seeking to improve development outcomes (e.g., Tull 2006; Naím 2007). Others praise China for its responsiveness to "recipient" needs and its willingness to get things done in a timely manner and reduce the administrative burden placed on overstretched public bureaucracies in the developing world. ${ }^{9}$ Some scholars have even suggested that Chinese aid could be less prone to waste, fraud, and abuse - and more effective in promoting economic growth - than aid from traditional Western donors because China maintains control over the activities it funds from the project initiation stage to the project completion stage (e.g., Bräutigam 2009, 2011b). ${ }^{10}$

The limited temporal coverage of existing data on Chinese aid makes it difficult to investigate the effects of Chinese aid on economic growth. Our analysis is thus limited to investigating whether the allocation of Chinese aid is driven by factors that are likely to increase its impact. To the extent that China's unwillingness to interfere in domestic politics renders the allocation of its aid more vulnerable to political capture by the leaders of recipient country governments, aid effectiveness will arguably suffer (Cohen 1995; Wright 2010; Briggs 2012, 2014). More generally, we know from cross-country studies that understanding the motives for granting aid is important because a donor's intent in allocating aid seems to impact the effectiveness of aid (e.g., Headey 2008; Bearce and Tirone 2010; Dreher et al. 2014).

The remainder of this paper is structured as follows: Section 2 explores some of the potential implications of China's principle of non-interference in the internal affairs of recipient countries for aid allocation and effectiveness. In Section 3, we introduce our method of estimation and data on leader characteristics and Chinese aid projects at the subnational level. Section 4 presents our main findings on the allocation of Chinese aid, while Section 5 concludes.

et al. (2012), and Brückner (2013). See Doucouliagos and Paldam (2008) for a review and meta-analysis of earlier studies on aid effectiveness.

${ }^{8}$ For an exception (on Arab donors), see Werker et al. (2009).

${ }^{9}$ See Dreher and Fuchs (forthcoming) and Strange et al. (2013) for references.

${ }^{10}$ In many cases, China remains involved in management of projects even after they have been completed (e.g., Bräutigam 2009). 


\section{The Demand Side of China's Aid Allocation}

A growing body of research analyzes the motives that drive China's aid provision. Dreher and Fuchs (forthcoming), for example, find that Chinese allocation decisions are significantly influenced by both political and commercial interests, but not by a recipient's institutional characteristics. ${ }^{11}$ Strange et al. (2014b) distinguish the determinants of China's official financing from those of ODA-like flows (as we do in the analysis provided below). They show that the allocation of highly concessional flows of Chinese official financing at the country level is primarily driven by political considerations, while economic interests predominate in the allocation of less concessional sources of official financing.

However, the motivations of aid donors provide only part of the picture. This should be particularly true in China's case, as the allocation of its aid is purportedly based on requests from recipient country governments. During our own interviews at China's Ministry of Commerce, which is Chinas lead aid agency, ministry officials emphasized that "the initiative generally comes from the recipient side." ${ }^{12}$ As Moss et al. (2007), Bueno de Mesquita and Smith (2007), Wright (2010), and Werker (2012) point out, recipients use aid strategically. Leaders may therefore not direct aid to those projects where developmental returns are maximized, but rather where their personal and parochial interests are best served (Cohen 1995; Moss et al. 2007; Wright 2010; Briggs 2014). Arguably, the quality and developmental impact of aid will suffer when personal and parochial interests are advanced. Werker (2012) also shows that aid windfalls render governments less accountable to their voters, encouraging them to choose policies that a majority of the voters would not support. As such, there is a risk that China's demand-driven policy could come at a substantial cost to the citizens of recipient countries.

Tull (2006) suggests that African state elites might be the biggest winners of China's increasing engagement in Africa. A request-based system of aid project preparation should, in principle, provide opportunities for political leaders to overtly or surreptitiously promote a subnational distribution of funding that helps cement allegiances with existing supporters and extend the patronage network to other politically relevant groups. ${ }^{13}$ This vulnerability

\footnotetext{
${ }^{11}$ China's disregard of institutional characteristics could still harm democracy and governance in recipient countries. Kersting and Kilby (2014) find eligibility for Chinese aid to be negatively associated with democracy. Bader (forthcoming a) finds that trade - but not other forms of China's economic cooperation - stabilizes autocracies.

${ }^{12}$ Authors' interview in June 2013. Officials within the Ministry of Health report a similar process: "We send medical teams to the areas of the country that are selected by the recipient government" (authors' interview in October 2014).

${ }^{13}$ We also know from previous research that many African leaders are both willing and able to steer West-
} 
should apply to any donor that gives recipient country governments a large amount of discretion in where to site development projects financed from abroad. However, China may be particularly vulnerable to this type of patronage because it distinguishes itself as being more responsive to the demands of its partner governments. Tull (2006: 467) notes that "Chinese aid tends to benefit the governments of receiving countries more directly than the policies of Western donors, who are preoccupied with the reduction of poverty." 14 We test this hypothesis by comparing the allocation of Chinese aid with the allocation of World Bank aid below.

Our central argument is that the demand-driven nature of the Chinese aid delivery process gives the domestic authorities in host countries substantial leeway to allocate funds to activities and locations that best suit their own interests. Therefore, understanding the nature of this process is key. ${ }^{15}$ The process typically begins when the host government proposes a project to the Economic and Commercial Counselor's office attached to China's in-country diplomatic mission. This office then submits the government's application - if it meets a minimum viability standard - to the Ministry of Commerce and the Ministry of Foreign Affairs in Beijing. A team of technical experts from the Ministry of Commerce then travels to the country that requested support to undertake a project feasibility assessment and budget in consultation with the domestic authorities. Upon their return to Beijing, the technical team initiates an inter-agency consultation process and prepares a final project proposal for the State Council's determination. ${ }^{16}$ If the State Council authorizes the project, the Ministry of Finance then transfers funds to the Ministry of Commerce and the procurement process begins. In cases where the host government is seeking a concessional loan worth more than RMB 20 million, its Ministry of Finance is expected to submit an application directly to the China EXIM Bank, which triggers the implementation of a project feasibility assessment. If the proposed project is deemed feasible, China EXIM Bank makes a recommendation to the Chinese Ministry of Commerce that the Chinese Government negotiate a "framework agreement" with the proposed borrower country,

ern aid to politically important regions, despite significant efforts by donors to minimize host government discretion (e.g., van de Walle 2007; Briggs 2014).

${ }^{14}$ Bräutigam (2011a: 761) also points out that this Chinese way of approaching country ownership "can lead to 'prestige' projects that do not appear to be poverty-reducing."

${ }^{15}$ Our description of this process relies heavily upon Davies et al. (2008) and Corkin (2011).

${ }^{16}$ Despite these formal procedures, Dornan and Brant (2014) argue that relatively little effort is made to conduct rigorous economic analysis of potential projects and project appraisal processes more generally remain weak. China's Ministry of Commerce tacitly acknowledged this weakness in April 2014 when it publicly released new policy guidance entitled "Measures for the Administration of Foreign Aid," which calls for stronger project appraisal, supervision, and evaluation processes (MOFCOM 2014). 
which is then followed by a project-specific loan agreement with China EXIM Bank.

Chinese aid packages and projects are often negotiated in high-level meetings with political leaders rather than publicly outlined in country assistance strategies that prioritize the specific economic growth and poverty reduction priorities for a country (AFDB et al. 2011: 126). ${ }^{17}$ Bräutigam (2011b) notes that "[f]or the Chinese, ownership starts (and sometimes ends) at the top. In cases where leaders do not coordinate with ministries, this can cause problems, as in Liberia where a president asked the Chinese to build a hospital upcountry, leaving the Liberian health ministry scrambling to figure out staffing for the remote location." 18

This demand-driven selection of Chinese aid projects is best understood in the context of one of the main principles of China's foreign aid policy: non-interference in the internal affairs of recipient countries and respect for their sovereignty. ${ }^{19}$ Beijing claims that it "never uses foreign aid as a means to interfere in recipient countries' internal affairs or seek political privileges for itself" (State Council 2011).

While evidence suggests that aid from "traditional" donors could also be vulnerable to misappropriation (Cohen 1995; Briggs 2014; and Masaki 2014), overall, aid from "traditional" sources appears to be less "demand-driven" than Chinese aid. Both "traditional" donors and China rhetorically embrace the principle of "country ownership," but there appear to be substantial differences in the way this principle is operationalized (e.g., Faust 2010). Nissanke and Söderberg (2011: 26) point out that "Chinese arrangements appear to be [...] much more flexible than the mechanisms offered by traditional donors, since the procedure adopted is seen to promote the sense of local ownership of aid-funded projects. Project selection is request-based: projects are initiated by borrowing countries, dependent on their preference, priority and circumstances." The United States and some European states, for example, are known for intentionally "bypassing" recipient governments that are corrupt or lacking strong public sector management institutions (Dietrich 2013; Knack 2014). Dornan and Brant (2014) provide qualitative evidence that China has a significantly

\footnotetext{
${ }^{17}$ China is currently in the process of developing aid strategies for each country but they are unlikely to be made public (authors' interview with Chinese aid expert in Beijing, September 2014).

${ }^{18}$ Additionally, China does not regularly participate in the various in-country donor coordination meetings and prefers staying outside the aid architecture dominated by the OECD (Bourguignon and Platteau 2014). According to one UK Department for International Development (DFID) official who served in two different countries in the late 2000s, "[c]oordinating donors was like herding cats. The Americans were a pain, but the Chinese just ignored us - they simply refused to participate" (Authors' interview, October 2014).

${ }^{19}$ The principle can be traced back to the Final Communiqué from the 1955 Bandung Conference and can still be seen in the most recent (2014) Chinese White Paper on Foreign Aid.
} 
less stringent project appraisal process and it assigns less effort to cost-benefit analysis of prospective projects.

Unsurprisingly, China's political non-interference approach seems to enjoy strong support among many African politicians. Consider the following statement from a Government of South Sudan official: "the U.S. and our other [Western] friends regularly tell us with certainty what we need. The Chinese appear more open to talking and to hearing what we want" (ICG 2012: 8). With a bit more of a rhetorical flourish, President Museveni of Uganda said: "[t]he Western ruling groups are conceited, full of themselves, ignorant of our conditions, and they make other people's business their business, while the Chinese just deal with you as one who represents your country, and for them they represent their own interests and you just do business" (Halper 2010: 100).

While African leaders have more discretion in the ways that they can use Chinese aid as compared to aid from "traditional" donors, the presence of discretion does not necessarily mean that governing elites will use it to steer aid from China to politically important groups. Leaders could, for example, use this discretion to address key poverty reduction and economic development challenges that have not attracted sufficient funding from Western donors. Indeed, many scholars, policy commentators, and journalists claim that African governments are using Chinese assistance to extend the reach and improve the quality of state-run electricity grids; strengthen water and sanitation systems; and establish or rehabilitate the highways, railroads, bridges and ports necessary for domestic and international commerce (e.g., Foster et al. 2008; Ravallion 2009; AFDB et al. 2011).

On the other hand, there is some anecdotal evidence that political leaders have (mis)used Chinese aid for political reasons. Downs (2011: 93-94), for example, notes that by providing a US $\$ 20$ billion loan that was used to address low-income housing needs and electricity shortages in areas of Venezuela that have traditionally supported the ruling party, China helped "finance [Hugo] Chávez's bid to win a third consecutive six-year term as president." Mthembu-Salter (2012: 20-21) similarly argues that Chinese foreign assistance helped President Kabila to win elections in the Democratic Republic of the Congo: "In 2006 Kabila campaigned on a ticket of 'cinq chantiers' (five tasks), which include new and better infrastructure, but without the high-profile efforts of [China Railways Construction Company] and Sinohydro to date he would have had precious few projects with which to seek to impress the electorate. There can be no question that the 'goodwill' decision of Chinese state-owned companies to lend money and start building three years before the poll date 
provided invaluable assistance to Kabila's successful re-election campaign." 20 Tull (2006: 467) also points out that "African leaders highly appreciate" China's prestige projects, such as the construction of presidential palaces and stadiums in recipient countries, "for their own political reasons."

However, while such anecdotes are illustrative and may help to illuminate the political economy logic of allocation within clientelist systems, we seek to test these claims using systematic evidence and quantitative methods. Do recipient countries' political leaders systematically site Chinese aid projects in areas that align with their selfish interests? And do they have more discretion over Chinese aid when compared to aid from "traditional" donors, such as the World Bank? We now turn to the econometric analysis.

\footnotetext{
${ }^{20}$ See also Jansson (2013) on Kabila's use of Chinese funding for his own political aims. It is also telling that in DR Congo the presidency itself rather than government line ministries administers Chinese projects. A former European embassy official in DR Congo thus concluded: "Chinese aid benefits those who are in power" (Authors' interview, September 2014).
} 


\section{Method and Data}

Our analysis covers subnational units of 47 African countries over the 2000-2011 period. ${ }^{21}$ These subnational units are administrative regions at the first and second subnational level, i.e., ADM1 regions like provinces, states, or governorates, and ADM2 regions like districts or municipalities. The GADM database on Global Administrative Areas provides shapefiles with information on subnational administrative regions and their boundaries. There are 709 ADM1 regions and 5,835 ADM2 regions in the 47 African countries covered in our sample. The borders of these divisions across Africa are shown in Figure 1, with strong borders representing ADM1 regions, and light borders ADM2 regions. We also use ethnographic regions as alternative subnational units. These ethnographic regions are based on the Geo-referencing of Ethnic Groups (GREG) data project by Weidmann et al. (2010), providing georeferenced information on ethnic groups. Overall, there are 609 different ethnic regions in our 47 African countries. ${ }^{22}$

Figure 1 around here

In order to test whether leaders' birthplaces and ethnic relationships matter for the allocation of Chinese aid, we estimate two sets of regressions, using ordinary least squares (OLS):

$$
\begin{gathered}
\text { Aid }_{i c t}=\alpha_{c t}+\sum_{j} \beta_{j} X_{i c}^{j}+\gamma \text { Birthregion }_{i c t}+\epsilon_{i c t}, \\
\text { Aid }_{i c t}=\alpha_{c t}+\delta_{i c}+\gamma \text { Birthregion }_{i c t}+\epsilon_{i c t}
\end{gathered}
$$

where $\alpha_{c t}$ represents country-year-fixed effects and $\delta_{i c}$ region-fixed effects. ${ }^{23}$

In what follows, we explain the remaining components of this regression framework. Our dependent variable $A i d_{i c t}$ is the natural logarithm of Chinese aid commitments allocated to region $i$ in country $c$ and year $t$ in constant 2009 US\$. ${ }^{24}$ This variable is constructed

\footnotetext{
${ }^{21}$ We exclude Western Sahara, a disputed territory, Somalia for the absence of a central government, and the five small island states of Cape Verde, Comoros, Mauritius, São Tomé and Príncipe, and Seychelles. Given potential concerns about the comprehensiveness of the 2012 data of the 1.1 version of AidData's China in Africa dataset, we follow Strange et al. (2014a) and exclude 2012.

${ }^{22}$ Note that we collapse different polygons (or regions) of the same country that share the same ethnic composition into one region.

${ }^{23}$ We also tried estimating our regressions with Poisson and Poisson pseudo-maximum likelihood (PPML) instead. However, most regressions including region fixed effects did not converge. Regressions without these fixed effects show similar results.

${ }^{24}$ We exclude flows coded as non-binding pledges or suspended projects. To avoid taking the log of zero, we added a value of US $\$ 1$ to our measure before taking logarithms.
} 
based on the dataset in Strange et al. (2013, 2014a) who provide project-level information of Chinese official finance activities in African countries. ${ }^{25}$ These data are coded based on AidData's Tracking Underreported Financial Flows (TUFF) methodology, which synthesizes and standardizes a large amount of unstructured information in the public domain. ${ }^{26}$ Despite the short time since the dataset's public release, it has already been used in a number of publications at the country-level (e.g., Grépin et al. 2014; Hendrix and Noland 2014; Hernandez 2014; Strange et al. 2014b; and Dreher and Fuchs forthcoming).

In total, the dataset covers 1,686 projects committed to 50 African countries, amounting to approximately US $\$ 84.8$ billion in official financing over the $2000-2012$ period. ${ }^{27}$ The largest recipients of Chinese official financing are Ghana, the Democratic Republic of Congo, and Ethiopia, with registered flows in the range of 7.9-12.1 billion constant 2009 US\$ (Strange et al. 2014a).

In order to take the data to the subnational level, we georeferenced the project-level data from version 1.1 of AidData's Chinese Official Finance to Africa dataset using the methodology described in Strandow et al. (2011). This methodology relies on a double-blind system, where two coders employ a defined hierarchy of geographic terms and independently assign uniform latitude and longitude coordinates, information about the precision of the data, and standardized names to each geographic feature of interest. If the location chosen by the two coders are not identical, then a senior researcher identifies the source of discrepancy and assigns the appropriate geocode. This process of arbitration between two independent coders by a third arbitrator ensures strict quality control, minimizing missed or incorrect locations. For projects with more than one location we georeferenced all locations. $^{28}$ Our application of this geocoding methodology yielded 1,898 project-locations

\footnotetext{
${ }^{25}$ Specifically, we rely on AidData's Chinese Official Finance to Africa Dataset, Version 1.1, which is available at http://china.aiddata.org/datasets/1.1.

${ }^{26}$ See Strange et al. (2014c) for a detailed description of this open source data collection methodology. One might argue that the open source nature of these data could threaten the reliability of our empirical tests. To the extent that leaders' birthplaces get better coverage in the sources used in Strange et al., a positive effect could reflect greater coverage rather than more projects. Arguably, this is particularly likely for small projects (as larger projects will receive some coverage in non-birthregions also). To test whether we are likely to miss small projects in leaders' birhregions, we replicate our region-fixed effects regressions with (log) average project size as dependent variable. We find project size to be unchanged at times a leader originates from a region. It is thus unlikely that a positive birthplace coefficient in our main regressions captures the effect of a large number of additional small projects that are discovered in leaders' birthplaces but not elsewhere.

${ }^{27}$ Unsurprisingly, the database does not contain any development projects in the remaining four African countries which recognize the Republic of China (Taiwan) rather than the Beijing government during these years. These countries are Burkina Faso, the Gambia, São Tomé and Príncipe, and Swaziland.

${ }^{28}$ Since we do not observe financial values at the project-location level, but only at the project level, we spread project amounts equally across all locations identified in each project.
} 
geocoded at the ADM1 level and 1,575 project-locations at the ADM2 level. ${ }^{29}$. In the analysis based on ethnographic regions, we can only include the 1,296 project-locations for which our geographical information is even more precise than the ADM2 level, such as an exact location or some nearby location.

We distinguish between two definitions of our dependent variable. First, we analyze the allocation of Chinese "aid" in the broadest sense as all official financing activities coded in Strange et al. (2013, 2014a) as either "ODA-like" or "OOF-like" according to the DAC definitions of Official Development Assistance (ODA) and Other Official Flows (OOF). ${ }^{30}$ Second, we restrict our analysis to those flows that were identified as being ODA-like. Figure 2 shows the allocation of official finance across ADM2 regions.

Figure 2 around here

A caveat for this dataset is that $35 \%$ of the projects lack information on their respective financial values. Although the bias is likely to be negligible since most of the missing values should correspond to small projects that did not attract much public attention, we take two actions to account for this weakness of the data. First, if we know there are Chinese projects in a particular subnational locality but we have no information about any of their monetary amounts, we set $A i d_{i c t}$ to missing. Second, we employ an alternative measure of the intensity of China's development activities across Africa: the logarithm of the number of projects (plus 1) carried out in a particular subnational region. While this alternative measure comes with the disadvantage that it does not account for the financial size of each project, we use it to test the robustness of our results. The number of projects per ADM2 region is shown in Figure 3.

Figure 3 around here

Comprehensive geocoded data for large bilateral, Western donors are not available for a longer period of time and for the entire African continent; therefore, we limit our analysis to a comparison with the World Bank, one of the largest "traditional" donors in Africa

\footnotetext{
${ }^{29}$ These numbers are substantially lower than the 3,545 locations our database covers. The reason is imprecise information on the exact locations of these projects.

${ }^{30}$ This includes official financing activities that cannot clearly be attributed to either ODA or OOF and are thus coded as "Vague (Official Finance)." Note that our measure excludes projects coded as "Official Investment" or "Military Aid." OOF is categorized as "[t]ransactions by the official sector with [developing] countries [...] which do not meet the conditions for eligibility as Official Development Assistance, either because they are not primarily aimed at development, or because they have a grant element of less than 25 per cent" (OECD DAC glossary).
} 
and one which is known for screening projects based on rigorous economic analysis and due diligence in vetting and preparing its projects (e.g., Jenkins 1997; Deininger et al. 1998). We rely on a georeferenced dataset provided by AidData (2015) in collaboration with the World Bank that consists of all World Bank projects approved between 2000 and 2011. The dataset includes 3,534 projects and 41,307 project locations, comprising total commitments of almost USD 370 bn (Dreher and Lohmann 2015). ${ }^{31}$ The dataset includes the date of approval for all projects and the amounts committed over their duration. We transform these values to constant 2009 USD. Again, we also distinguish between concessional flows (from the International Development Association, IDA) and non-concessional flows (from the International Bank for Reconstruction and Development, IBRD) and extract the number of projects per region as additional variable of interest. Information on World Bank projects is available with different degrees of precision: Some projects are recorded in a limited geographical area, such as a village or city. Others are recorded at more aggregate levels, such as a municipality, a district or greater administrative region. We exclude those projects that are nation-wide in scope, for which no or unclear information on their location is provided, and projects that are allocated to the central government and therefore cannot be attributed to a specific region. In total, about 40 percent of all projects are assigned to a distinguishable location (Dreher and Lohmann 2015).

Our main variable of interest is a binary indicator variable Birthregion $_{\text {ict }}$, which is equal to 1 if the political leader of country $c$ in year $t$ was born in administrative region $i$, and 0 otherwise. We apply the definition of countries' effective leaders from Goemans et al.'s (2009) Archigos dataset, updated in Dreher et al. (2014). ${ }^{32}$ In order to assign latitude and longitude coordinates to the birthplaces of the political leaders of African countries, we follow Strandow et al. (2011). We were able to attribute leaders to 76.7 (75.4) percent of the country-years covered at the ADM1 (ADM2) level; the remaining leaders were either foreign-born or we were not able to gather sufficient information to georeference them as fine-grained as necessary for ADM1 (ADM2). Figure 4 shows the leaders' birth regions in our sample at the ADM2 level.

For the analyses based on ethnic regions, we construct an analogous indicator variable Ethnicregion $_{\text {ict }}$, which is equal to 1 if the political leader of country $c$ in year $t$ is member of the ethnic group that lives in ethnographic region $i$, and 0 otherwise. We use data

\footnotetext{
${ }^{31}$ See Findley et al. (2011) for a detailed description of an earlier release of these data.

${ }^{32}$ Archigos applies the following coding rules: The effective ruler corresponds generally to the prime minister in parliamentary regimes, to the president in presidential regimes, and to the chairman of the party in communist states. Information on the dates of leaders' entrance and exit from power is taken from Archigos and verified using DBpedia and, if necessary, Wikipedia.
} 
on leaders' ethnic groups from Parks (2014), ${ }^{33}$ and code their latitudinal and longitudinal coordinates using Geonames. ${ }^{34}$ Table 5 lists all domestic-born leaders together with their administrative birth regions and ethnicities.

$X_{i c}$ represents our time-invariant control variables. We include nighttime light intensity as a proxy for economic activity at the subnational level. ${ }^{35}$ The National Oceanic and Atmospheric Administration (NOAA) provides annual data for pixels that correspond to slightly less than one square kilometer on a scale from 0 to 63 , with higher values implying more intense nighttime light. ${ }^{36}$ The variable Light $2000_{i c}$ corresponds to the logarithm of the average nighttime light intensity of the pixels in region $i$ of country $c$ in 2000, i.e., at the beginning of our sample period. ${ }^{37}$

We further control for the geographical and human-population size of subnational regions. The variable $A r e a_{i c}$ is directly calculated from the shapefile of subnational boundaries, while Population $2000_{i c}$ is based on high resolution data on the spatial distribution of the world population in 2000 by CIESIN. We add the binary variable Capitalregion ic $_{\text {c }}$ that takes the value of one if the capital city of country $c$ is located in region $i$ in order to account for the specific role played by the country's capital. To test the claim that Chinese aid is driven by a desire for access to natural resources, we compute Minesic, which is defined as the log of the sum of mineral facilities in each subnational region $i$ according to Mineral Resource Data System of the United States Geological Survey (USGS 2005). ${ }^{38}$ We build

\footnotetext{
${ }^{33}$ We used biographies of political leaders provided by the Barcelona Centre for International Affairs (http://www.cidob.org/es/documentacion/biografias_lideres_politicos) and the DBpedia profile page of the respective leader (http://dbpedia.org) as secondary sources.

${ }^{34}$ See http://www.geonames.org. We record locations with five decimal places of precision. As secondary source we rely on the American National Geospatial Intelligence Service (NGA) (http: //geonames.nga.mil/ggmagaz).

${ }^{35}$ Changes in nighttime light intensity have been shown to be highly correlated with changes in regional GDP at both the country level and the level of subnational localities (Henderson et al. 2012; Hodler and Raschky 2014a). A main advantage of nighttime light intensity is its availability at the regional level, which is particularly useful in the African context where regional GDP estimates are typically poor or unavailable.

${ }^{36}$ Weather satellites from the U.S. Air Force circle the Earth 14 times a day and measure light intensity. The NOAA uses observations from evenings during the dark half of the lunar cycle in seasons when the sun sets early. It removes observations that are likely to be affected by, e.g., cloud coverage, fires or other ephemeral lights.

${ }^{37}$ We follow Michalopoulos and Papaioannou (2013, 2014) and Hodler and Raschky (2014a,b) in adding 0.01 to the average nighttime light intensity before taking its logarithm. Doing so ensures that we do not lose observations with a reported nighttime light intensity of zero. Using the year 2000 minimizes potential reversed causality.

${ }^{38}$ This cross-sectional dataset on historical and current mining facilities includes mines, plants, mills and refineries of many mineral commodities such as Coal, Iron Ore, Copper, Gold, Silver, and Zinc. We added one before taking the log.
} 
a second indicator of resource wealth using data provided by Lujala et al. (2007). The variable $\mathrm{OilGas}_{i c}$ takes the value of one if parts of an oil or gas field overlap with the area of subnational region $i$. In order to test China's potential interest in facilitating the import and export of goods to and from Africa, we construct a binary indicator variable Port ${ }_{i c}$ that is one if a port is located in region $i$, using data from the World Port Index 2011 (NGA 2011). We compute the total length of roads per square kilometer (RoadDensity ic $_{\text {) using }}$ geographic data from CIESIN (2013). We expect this variable to exhibit a negative coefficient if Chinese projects follow recipient need. A positive coefficient in turn might signal the relevance of the ease of project implementation (or doing business more generally).

Comparing the models in Equation 1 and 2, the former has two advantages. First, the omission of region-fixed effects allows us to also exploit between-region variation, which might be important to identify the relationship between birthplaces and aid absent large variation in the leaders' birth regions and ethnic regions. ${ }^{39}$ Second, this specification allows us to include variables that vary across regions exclusively. While the focus of our analysis is on leaders' birth and ethnic regions, the inclusion of these variables facilitates comparison with the country-level literature on the allocation of aid. A shortcoming of this approach is that a statistically significant effect of these regions on aid might be spurious and could simply reflect the fact that certain regions receive more aid than others, for reasons unrelated to leaders that we do not control for in our models. Equation 2 precludes such spurious results by exploiting region-specific variation over time exclusively. While this specification is the more rigorous one, we lose substantial variation, which makes identifying the relationship between aid and regions more difficult. Below we go one step further and also control for the last year before the political leaders came to power, and the first year after they were out of power. In all equations, we cluster standard errors by leaders. ${ }^{40}$

Table 2 provides summary statistics at the level of ADM1 regions. On average, each African region receives 0.2 Chinese projects or US\$ 6.5 million in development finance per year, of which US\$1.5 million come in the form of ODA-like flows. 6.7 percent of regionyears are coded as being the respective leader's birth region. The next section reports the regression results.

Table 2 around here

\footnotetext{
${ }^{39}$ Note that leader changes are infrequent. In our sample we observe 39 changes in birthregions at the ADM1 level and 43 changes at the ADM2 level.

${ }^{40}$ Note that country-years with power transitions or without domestic-born leaders receive a separate country-specific leader ID.
} 


\section{Results}

Table 3 shows the results for Chinese aid from our regressions of Equation 1, which includes country-year fixed effects, but no region-fixed effects. Columns 1 and 2 focus on total aid flows for ADM1 and ADM2 regions, respectively. As can be seen, aid amounts increase with economic activity (proxied by nighttime light intensity) and the geographic size of the administrative units, at least at the five percent level of significance. At the one percent level, regions containing the country's capital receive more aid. ADM2 regions with larger populations and the presence of ports, and ADM1 regions with mines receive significantly more aid (at the ten percent level), while the availability of oil or gas, and road density are not significant at conventional levels. Taken together, these results imply that subnational need does not drive the allocation of Chinese aid within African countries. Specifically, while more aid is allocated to poorer countries according to the results in Dreher and Fuchs (forthcoming), we find that poorer regions within countries receive less aid (that is, countries with less nighttime light intensity, after controlling for regional population size). These discrepancies highlight the importance of taking the aid allocation literature to the subnational level. The lack of robust evidence that the availability of natural resources is a dominant driver of aid is less surprising: Dreher and Fuchs (forthcoming) also do not find natural resources to play a significant role at the cross-country level. Interestingly, the only significant positive effect (mine presence at ADM1 level) gets lost when we restrict the sample to ODA-like flows in column 3, i.e., aid in the stricter sense. This is also in line with the findings in Strange et al. (2014b) that China's commercial motives matter more for less concessional flows than for ODA-like flows.

Table 3 around here

Turning to our variable of interest, the results show that larger aid amounts go to the ADM1 and ADM2 birth regions of a country's political leader, both at the five percent level of significance. The coefficients imply an increase in aid flows by almost 100 percent to ADM1 regions containing the political leader's birthplace and a corresponding increase of almost 75 percent for ADM2 regions.

Columns 3 and 4 replicate the analysis focusing on ODA-like flows rather than all official finance, while columns 5 and 6 focus on the total number of official finance projects rather than total official finance amounts. The results for most of our explanatory variables are qualitatively similar to those in columns 1 and 2. It is however noteworthy that the density of the road network does have a statistically significant positive effect in the additional 
regressions at the ADM2-level, and that the presence of oil and gas tends to reduce the number of projects there. The results for our main variable of interest are weaker. At the ADM1-level, the coefficients of birth regions, while still positive, are no longer statistically significant at conventional levels. At the ADM2-level, ODA-like flows and the (total) number of projects are larger in birth regions, at the ten percent level of significance. Quantitatively, we find that the birth regions of political leaders receive an increase in ODA of 48 percent and in the number of projects of 4 percent at the ADM2-level. While Strange et al. (2014b) show that political variables are more important for ODA-like flows compared to OOF-like flows at the country-level, our results point at the opposite direction. It seems that Chinese political interests predominate in the cross-national allocation of ODA, while African political interests predominate in the subnational allocation of ODA and foreign assistance broadly defined.

In Table 4 we report our regressions of Equation 2, i.e., we replace our time-invariant control variables with region fixed effects. Since controlling for both country-year and region-fixed effects is likely to absorb a large share of the variation in our variable of interest, it represents the more conservative specification. Controlling for the set of fixed effects makes the existence of a spurious relationship between birthplace and aid flows unlikely. As the inclusion of region-fixed effects makes it more difficult to identify statistically significant results, it is not surprising that the coefficient estimates become insignificant at conventional levels for all three specifications at the ADM2-level. It is however remarkable that the results for ADM1 regions tend to become even stronger with the inclusion of region-fixed effects, in particular for total flows with a coefficient being statistically significant at the one percent level. The coefficient estimates in columns 1 and 3 suggest that total flows increase by around 195 percent when regions become the political leader's birth region; and ODA-like flows increase by slightly more than 75 percent. ${ }^{41}$

Table 4 around here

In a next step we include the binary indicators Prebirth Pict $_{\text {and Postbirth }}$ ict to our

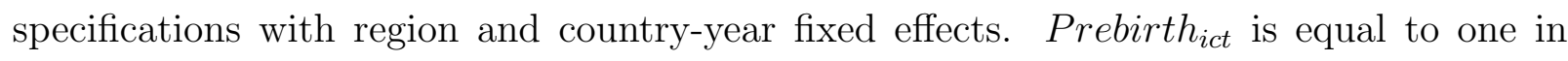
the last year before a region becomes the birth region of the (new) political leader, while Postbirth $_{\text {ict }}$ is equal to one in the first year in which a region is no longer the birth region of the (old) political leader. A statistically significant coefficient on Prebirth ict $_{\text {would }}$

\footnotetext{
${ }^{41}$ We have looked at the potential heterogeneity of these effects. We find no evidence that the effect depends systematically and significantly on, e.g., the quality of the political institutions, perceived corruption, the country's natural resource endowment, or voting patterns in the UN General Assembly.
} 
imply that the political leaders' birth regions receive more Chinese aid already before the political leaders get into power, which would question our interpretation that these regions receive more Chinese aid exactly because the political leaders favor them. To the contrary,

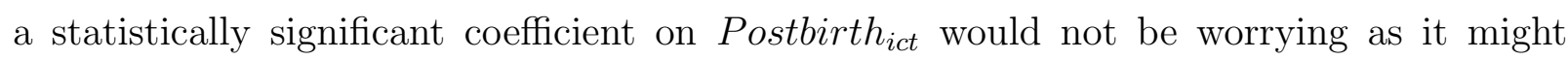
indicate that part of the aid pledged for a birth region is formally committed with some delay.

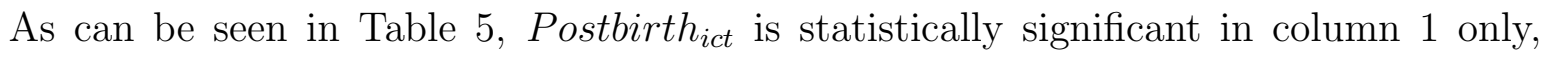
suggesting that regions that were a birth region in the previous year, but are no longer a birth region still get more total aid flows than they get in other years in which they are not the political leader's birth region. More importantly, Prebirth ict $_{\text {is not statistically }}$ significant in any of the specifications (and even negative in the majority of cases). This finding provides remarkably strong support for our interpretation that there is a causal effect from being the political leader's birth region to getting more Chinese aid. ${ }^{42}$

Table 5 around here

We next turn to the allocation of World Bank aid in order to test whether aid from a donor with strict project appraisal policies and procedures can be misappropriated to the same extent as aid from China, with its strong emphasis on non-interference. We again start by analyzing total official flows in columns 1 and 2, then restrict the study object to ODA-like flows in columns 3 and 4 , and finally look at project numbers in columns 5 and 6. Table 6 shows results excluding region fixed effects. As can be seen, the major cross-sectional determinants of subnational aid allocation are by and large similar for the World Bank as for China. The main differences are that the World Bank does not robustly focus on the capital region, but allocates more aid to populous regions, according to all regressions. It also allocates more to regions with a port. Table 6 further suggests that the World Bank allocates more aid to ADM2 birth regions of the political leaders, but not to their ADM1 birth regions.

Table 6 around here

However, the regressions with region fixed effects reported in Table 7 provide no evidence that (ADM1 or ADM2) regions get more World Bank aid in times in which they

\footnotetext{
${ }^{42}$ We also run regressions controlling for two years before and after transitions in political leadership. Our conclusions are not affected by this.
} 
are the current political leader's birth region than in other times. ${ }^{43}$ Hence, it seems that African leaders cannot (mis)use World Bank aid for patronage politics in the same way they can (mis)use Chinese aid.

Table 7 around here

We expect that the regional favoritism related to the allocation of aid is not limited to the geographic location of the political leaders' birthplace. Instead, political leaders want people from their own ethnic group to be beneficiaries from foreign aid projects. This would extend the geographical focus from the narrow birthplace region to a wider set of locations with inhabitants that share the same ethnicity with the current political leader. To analyze the degree of potential ethnic favoritism in aid allocation, we change the unit of observation from subnational, federal units to ethnographic regions (GREG regions) within a country.

We commence this GREG region level analysis by estimating Equation 1 (which does not control for region fixed effects). The results in Table 8 show that ethnographic regions with the same ethnicity as the current political leader are more likely to receive Chinese aid (columns 1-3) as well as World Bank aid (columns 4-6). The coefficients of the remaining control variables follow a similar pattern as the results using the ADM2 regions. Richer ethnographic regions (again measured by the level of nighttime light intensity in 2000), regions that include the country's capital and regions with more mining operations receive more Chinese and World Bank aid compared to other regions. Interestingly, the effect of mines on the allocation of Chinese aid is statistically significant at the one or five percent level for all aid variables. Recall, the coefficient of mines was only weakly significant for total Chinese aid in the regressions using ADM2 data and insignificant with the ADM1 data. In contrast to China, the World Bank seems to systematically favor more populated ethnic regions and ethnic areas with better infrastructure (ports and road density).

Table 8 around here

Table 9 replicates the regressions for the ethnographic regions populated by the political leaders' ethnic group including region fixed effects. We again look at the amount of total aid, ODA-like flows, and the number of (total) aid projects from both China and the World Bank. Controlling for region fixed effects, we find no evidence that the political

\footnotetext{
${ }^{43}$ These results remain unchanged if we further add Preethnic $i c t$ and Postethnic $c_{i c t}$ to the fixed effects regressions reported in Table 7.
} 
leaders' ethnographic regions receive more foreign aid. ${ }^{44}$ We offer four explanations for these insignificant results. One, the larger size of the GREG regions reduces variation over time, making it more difficult to identify the effect given the inclusion of region-fixed effects. Two, the substantially lower number of aid projects that we were able to geocode compared to ADM1 and ADM2 regions increases noise, again making the identification of significant effects more difficult. Three, the number of changes in leaders' ethnicity is smaller than changes in birthregions. ${ }^{45}$ Four, of course, political leaders might not target their ethnic groups with Chinese or World Bank aid.

Table 9 around here

\section{Conclusions}

China prides itself on providing foreign aid in a demand-driven process in order to meet the needs of recipients. Many scholars also give Beijing credit for providing their African government counterparts with more "ownership" and "policy space" (e.g., Bräutigam 2011b; Kragelund 2011; Reisen and Stijns 2011). However, while good intentions might guide this policy, and advance the principle of country ownership put forward by OECD donors, it is unclear who Beijing expects to ultimately benefit from such a policy. "Recipient need" could refer to the needs of the general population or to governing elites and their clients, but the interests of these groups do not necessarily align. Our results based on a new georeferenced dataset of Chinese development finance across African localities highlight the potential development risks of this "on-demand" approach to aid allocation: controlling for objective indicators of recipient needs and various fixed effects, more Chinese aid projects are sited in the birth regions of African leaders, while similar results are absent from the allocation of World Bank aid. When provided with the discretion to do so, the average African leaders seem to pay favorites by allocating substantial additional resources to their home constituency to the detriment of citizens who face greater economic needs. ${ }^{46}$

\footnotetext{
${ }^{44}$ These results remain unchanged if we further add Prebirth $h_{i c t}$ and Postbirth $h_{i c t}$ to the fixed effects regressions reported in Table 9.

${ }^{45}$ We observe 25 changes in our sample, compared to 39 changes at the ADM1 level and 43 changes at the ADM2 level.

${ }^{46}$ While we have not done so in this paper, one can imagine sector-specific analysis of need using different dependent variables. Does education aid go to areas with the lowest literacy rates? Does health aid go to regions with the highest child mortality, lowest life expectancy, or highest rates of communicable disease? We are hopeful that specialists in different issue areas will conduct similar subnational analyses.
} 
A concern that follows from our main finding is the possibility that the subnational allocation of Chinese aid might diminish its ultimate effectiveness. Previous research suggests the bulk of the variation in project success to be at the project- rather than the countrylevel (Denizer et al. 2013). There is also a growing body of evidence that the allocation of aid to a narrow set of political constituencies is unlikely to improve the provision of public goods or facilitate significant improvements in development outcomes (e.g., Cohen 1995; Wright 2010; Dionne et al. 2013). As Briggs (2014: 202-203) puts it, "a lot of successfully built roads may not help national growth if they are built in areas that are politically but not economically - important. The individual projects may have succeeded, and some key constituencies may enjoy these roads, but this alone does not ensure that the roads will improve the national economy."

Therefore, while this paper only provides empirical evidence related to the subnational determinants of aid allocation, it raises broader questions about the degree to which inefficiency in the allocation and use of public resources affects development outcomes, such as economic growth and poverty reduction. Previous studies establish a link between inefficient public spending and inferior development outcomes (e.g., Lanjouw and Ravallion 1999; Ravallion 2000; Rajkumar and Swaroop 2008). However, we do not yet know whether or to what extent the political targeting of Chinese aid diminishes its ultimate development impact. This is an important avenue for future research. ${ }^{47}$

While our empirical results show that the selection of Chinese aid projects is vulnerable to regional favoritism and this source of targeting bias might adversely impact the effectiveness of Chinese aid, things could look different at the project implementation stage. Chinese aid money often does not leave Chinese hands (and China sometimes controls management after the project has been completed); therefore, Chinese aid may be less prone to corruption or favoritism than "traditional" aid at later stages of the aid cycle. As importantly, a large number of additional features likely influence the effectiveness of aid, including the amount of red tape involved in setting up the projects, the design of and compliance with conditions accompanying aid from some donors but not others, the choice of project aid over budget support, and the specific sectors a donor prioritizes. We leave these important questions for future research.

The findings reported here also open up new avenues for research on the specific causal

\footnotetext{
${ }^{47}$ Dreher and Lohmann (2015) investigate the effectiveness of World Bank aid at the regional level. They do not find a significant effect of aid on nighttime light growth at the ADM1 or ADM2 level. However, their identification strategy relies on reduced country-level aid following the crossing of the IDA's income threshold for receiving concessional aid. This strategy cannot be applied to test the effectiveness of China's aid.
} 
mechanisms that produce subnational patterns of aid allocation that are based on political rather than developmental criteria. At least four mechanisms ought to be explored: the possibility that African leaders are intentionally using more flexible sources of aid to cement their domestic political bases (Moss et al. 2007; Bader forthcoming b); the possibility that African leaders might be economically privileging their home regions in anticipation of returning to these places after leaving office; the possibility that the Chinese government itself is directly or indirectly promoting its own domestic political culture wherein elected leaders disproportionately allocate public resources to their home villages (Mu and Zhang 2014); and the possibility that Chinese firms in Africa with close ties to the leaders of African countries influence the project identification and selection process (Chen and Orr 2009; Dornan and Brant 2014; Zhu forthcoming). To the extent that future research reveals significant cross-donor variation in vulnerability to this source of targeting bias, it will also be important to examine whether aid from donors with more thoroughgoing approaches to project appraisal is less subject to political capture. 


\section{References}

Acemoglu, Daron, and James Robinson. 2012. Fancy Schools. Why Nations Fail Blog. February 27, 2012. Available at http://whynationsfail.com/blog/2012/2/27/fancy-schools . html (last accessed 24 February 2015).

African Development Bank (AFDB), Organisation for Economic Co-operation and Development (OECD), United Nations Development Programme (UNDP), United Nations Economic Commission for Africa (UNECA). 2011. African Economic Outlook 2011. Tunis, Tunisia: AFDB. Accessed on 01 November 2014 at http://www.afdb.org/ fileadmin/uploads/afdb/Documents/Generic-Documents/Media_Embargoed_Content/ EN-AE0_2011_embargo\%206\%20Juin.pdf

AidData. 2015. Geocoded Data from the World Bank IBRD-IDA, Version 1.0. Available at http://aiddata.org (accessed 14 January 2015).

Alesina, Alberto, and David Dollar. 2000. Who Gives Foreign Aid to Whom and Why? Journal of Economic Growth 5, 1: 33-63.

Bader, Julia. Forthcoming a. China, Autocratic Patron? An Empirical Investigation of China as a Factor in Autocratic Survival. International Studies Quarterly.

Bader, Julia. Forthcoming b. Propping Up Dictators? Economic Cooperation from China and its Impact on Authoritarian Persistence in Party and Non-party Regimes. European Journal of Political Research.

Barkan, Joel D., and Michael Chege. 1989. Decentralising the State: District Focus and the Politics of Reallocation in Kenya. Journal of Modern African Studies 27, 3: 431-453.

Bates, Robert H. 1974. Ethnic Competition and Modernization in Contemporary Africa. Comparative Political Studies 6, 4: 457-484.

Bearce, David H., and Daniel C. Tirone. 2010. Foreign Aid Effectiveness and the Strategic Goals of Donor Governments. Journal of Politics 72, 3: 837-851.

Bourguignon, François and Jean-Philippe Platteau. 2014. The Hard Challenge of Aid Coordination. World Development In Press.

Bräutigam, Deborah. 2009. The Dragon's Gift: The Real Story of China in Africa. Oxford, UK: Oxford University Press.

Bräutigam, Deborah. 2011a. Aid 'With Chinese Characteristics': Chinese Foreign Aid and Development Finance Meet the OECD-DAC Aid Regime. Journal of International Development 23, 5: 752-764.

Bräutigam, Deborah. 2011b. Testimony on China's Growing Role in Africa before the United States Senate Committee on Foreign Relations Subcommittee on African Affairs. November 1, 2011. Available at http://www.foreign.senate.gov/imo/media/doc/ Deborah_Brautigam_Testimony.pdf (last accessed 24 February 2015).

Briggs, Ryan C. 2012. Electrifying the Base? Aid and Incumbent Advantage in Ghana. Journal of Modern African Studies 50, 4: 603-624.

Briggs, Ryan C. 2014. Aiding and Abetting: Project Aid and Ethnic Politics in Kenya. World Development 64: 194-205.

Brückner, Markus. 2013. On the Simultaneity Problem in the Aid and Growth Debate. Journal of Applied Econometrics 28, 1: 126-150. 
Bueno de Mesquita, Bruce, and Alastair Smith. 2007. Foreign Aid and Policy Concessions. Journal of Conflict Resolution 51, 2: 251-284.

Burgess, Robin, Remi Jedwab, Edward Miguel, Ameet Morjaria, and Gerard Padró i Miquel. Forthcoming. The Value of Democracy: Evidence from Road Building in Kenya. American Economic Review.

Center for International Earth Science Information Network (CIESIN). 2013. Global Roads Open Access Data Set, Version 1 (gROADSv1). Columbia University, and Information Technology Outreach Services - ITOS - University of Georgia. Palisades, NY: NASA Socioeconomic Data and Applications Center (SEDAC). Available at http://dx.doi. org/10.7927/H4VD6WCT.

Chen, Chuan and Ryan Orr. 2009. Chinese Contractors in Africa: Home Government Support, Coordination Mechanisms, and Market Entry Strategies. Journal of Construction Engineering and Management 1135, 11: 1201-1210.

Clemens, Michael A., Steven Radelet, Rikhil R. Bhavnani, and Samuel Bazzi. 2012. Counting Chickens when they Hatch: Timing and the Effects of Aid on Growth. Economic Journal 122, 561: 590-617.

Cohen, John M. 1995. Ethnicity, Foreign Aid, and Economic Growth in Sub-Saharan Africa: The Case of Kenya. HIID Development Paper No. 520. Cambridge, MA: Harvard Institute for International Development.

Corkin, Lucy. 2011. Redefining Foreign Policy Impulses toward Africa: The Roles of the MFA, the MOFCOM and China Exim Bank. Journal of Current Chinese Affairs 40, 4: 61-90.

Davies, Martyn, Hannah Edinger, Nastasya Tay, and Sanusha Naidu. 2008. How China Delivers Development Assistance to Africa. Centre for Chinese Studies. Stellenbosch, South Africa: University of Stellenbosch.

Deininger, Klaus, Lyn Squire, and Swati Basu. 1998. Does Economic Analysis Improve the Quality of Foreign Assistance?. World Bank Economic Review 12, 3: 385-418.

De Luca, Giacomo, Roland Hodler, Paul A. Raschky, and Michele Valsecchi. 2015. Ethnic Favoritism: An Axiom of Politics? CESifo Working Paper 5209. Munich, Germany: CESifo.

Denizer, Cevdet, Daniel Kaufmann, and Aart Kraay. 2013. Good Countries or Good Projects? Macro and Micro Correlates of World Bank Project Performance. Journal of Development Economics 105: 288-302.

Dietrich, Simone. 2013. Bypass or Engage? Explaining Donor Delivery Tactics in Foreign Aid Allocation. International Studies Quarterly 57, 4: 698-712.

Dionne, Kim Yi, Eric Kramon, and Tyson Roberts. 2013. Aid Effectiveness and Allocation: Evidence from Malawi. Paper presented at the Conference "Research Frontiers in Foreign Aid" at Princeton University, April 26-27.

Do, Quoc-Anh, Kieu-Trang Nguyen, and Anh N. Tran. 2013. One Mandarin Benefits the Whole Clan: Hometown Favoritism in an Authoritarian Regime. Paper presented at the 2014 Annual Congress of the European Economic Association in Toulouse, France. http://www. eea-esem. com/files/papers/EEA-ESEM/2014/2185/Mandarin\% 200 ct $\% 2030 \% 202013$. pdf. 
Dornan, Matthew and Philippa Brant. 2014. Chinese Assistance in the Pacific: Agency, Effectiveness and the Role of Pacific Island Governments. Asia \& the Pacific Policy Studies 1, 2: 349-363

Doucouliagos, Hristos, and Martin Paldam. 2008. Aid Effectiveness on Growth: A Meta Study. European Journal of Political Economy 24, 1: 1-24.

Downs, Erica. 2011. Inside China, Inc: China Development Bank's Cross-Border Energy Deals. John L. Thornton China Center Monograph Series No. 3. Washington, DC: Brookings Institution.

Dreher, Axel, Vera Eichenauer, and Kai Gehring. 2014. Geopolitics, Aid and Growth. CEPR Discussion Paper No. 9904.

Dreher, Axel, and Andreas Fuchs. Forthcoming. Rogue Aid? An Empirical Analysis of China's Aid Allocation. Canadian Journal of Economics.

Dreher, Axel, Richard Jong-A-Pin, and Shu Yu. 2014. The Alma Mater Effect. Does Foreign Education of Political Leaders Influence Voting Behavior in the United Nations General Assembly? Mimeo.

Dreher, Axel, and Steffen Lohmann. 2015. Aid and Growth at the Regional Level. Mimeo.

Dreher, Axel, Peter Nunnenkamp, and Rainer Thiele. 2011. Are 'New' Donors Different? Comparing the Allocation of Bilateral Aid Between nonDAC and DAC Donor Countries. World Development 39, 11: 1950-1968.

Dreher, Axel, Jan-Egbert Sturm, and James Vreeland. 2009. Development Aid and International Politics: Does Membership on the UN Security Council Influence World Bank Decisions? Journal of Development Economics 88, 1: 1-18.

Faust, Jörg. 2010. Policy Experiments, Democratic Ownership and Development Assistance. Development Policy Review 28, 5: 515-534.

Faye, Michael, and Paul Niehaus. 2012. Political Aid Cycles. American Economic Review 102, 7: 3516-3530.

Findley, Michael. G., Josh Powell, Daniel Strandow, and Jeff Tanner. 2011. The Localized Geography of Foreign Aid: A New Dataset and Application to Violent Armed Conflict. World Development 39, 11: 1995-2009.

Foster, Vivien, William Butterfield, Chuan Chen, and Nataliya Pushak. 2008. Building Bridges: China's Growing Role as Infrastructure Financier for Sub-Saharan Africa. Washington, DC: World Bank/PPIAF.

Franck, Raphaël, and Ilia Rainer. 2012. Does the Leader's Ethnicity Matter? Ethnic Favoritism, Education and Health in Sub-Saharan Africa. American Political Science Review 106, 2: 294-325.

Francois, Patrick, Ilia Rainer, and Francesco Trebbi. Forthcoming. How is Power Shared in Africa? Econometrica.

Franken, Nathalie, Bart Minten, and Johan F.M. Swinnen. 2012. The Political Economy of Relief Aid Allocation: Evidence from Madagascar. World Development 40, 3: 486-500.

Frey, Bruno S., and Friedrich Schneider. 1986. Competing Models of International Lending Activity. Journal of Development Economics 20, 3: 225-245.

Goemans, Hein E., Kristian S. Gleditsch, and Giacomo Chiozza. 2009. Introducing Archigos: A Data Set of Political Leaders. Journal of Peace Research 46, 2: 269-283. 
Grépin, Karen A., Victoria Y. Fan, Gordon C. Shen, and Lucy Chen. 2014. Chinas Role as a Global Health Donor in Africa: What Can We Learn from Studying Under Reported Resource Flows?. Globalization and Health 10, 84: 1-11.

Halper, Stefan. 2010. The Beijing Consensus: How China's Authoritarian Model Will Dominate the Twenty-first Century. New York, NY: Basic Books.

Headey, Derek. 2008. Geopolitics and the Effect of Foreign Aid on Economic Growth: 1970-2001. Journal of International Development 20: 161-180.

Henderson, Vernon J., Adam Storeygard, and David N. Weil. 2012. Measuring Economic Growth from Outer Space. American Economic Review 102, 2: 994-1028.

Hendrix, Cullen, and Marcus Noland. 2014. Confronting the Curse: The Economics and Geopolitics of Natural Resource Governance. Washington DC: Peterson Institute for International Economics.

Hernandez, Diego. 2014. Is Non-DAC Aid Challenging World Bank Conditionality? Paper presented at the Workshop on South-South Development Cooperation at Heidelberg University, September 26-27.

Hodler, Roland, and Paul A. Raschky. 2014a. Regional Favoritism. Quarterly Journal of Economics 129, 2: 995-1033.

Hodler, Roland, and Paul A. Raschky. 2014b. Economic Shocks and Civil Conflict at the Regional Level. Economics Letters 124, 3: 530-533.

International Crisis Group (ICG). 2012. China's New Courtship in South Sudan. Africa Report No. 186. 4 April 2012. New York: ICG.

Jablonski, Ryan S. 2014. How Aid Targets Votes: The Impact of Electoral Incentives on Foreign Aid Distribution. World Politics 66, 2: 293-330.

Jansson, Johanna. 2013. The Sicomines Agreement Revisited: Prudent Chinese Banks and Risk-taking Chinese Companies. Review of African Political Economy 40, 135: 152-162.

Jenkins, Glenn P. 1997. Project Analysis and the World Bank. American Economic Review 87, 2: $38-42$.

Kasara, Kimuli. 2007. Tax Me if You Can: Ethnic Geography, Democracy, and the Taxation of Agriculture in Africa. American Political Science Review 101, 1: 159-172.

Kersting, Erasmus, and Christopher Kilby. 2014. Aid and Democracy Redux. European Economic Review 67: 125-143.

Kilby, Christopher. 2009. The Political Economy of Conditionality: An Empirical Analysis of World Bank Loan Disbursements. Journal of Development Economics 89, 1: 51-61.

Knack, Stephen. 2014. Building or Bypassing Recipient Country Systems: Are Donors Defying the Paris Declaration? Journal of Development Studies 50, 6, 839-854.

Kragelund, Paul. 2011. Emerging Partners and Governance: Does the Rise of Emerging Partnerships Increase Ownership of Development Policies and Widen the Policy Space for African Governments? Special African Economic Outlook 2011 Paper. Paris, France: OECD Development Centre.

Kramon, Eric, and Daniel N. Posner. 2012. Ethnic Favoritism in Primary Education in Kenya. Mimeo.

Kramon, Eric, and Daniel N. Posner. 2013. Who Benefits from Distributive Politics? How the Outcome One Studies Affects the Answer One Gets. Perspectives on Politics 11, 2: 
461-474.

Kuziemko, Ilyana, and Eric Werker. 2006. How Much Is a Seat on the Security Council Worth? Foreign Aid and Bribery at the United Nations. Journal of Political Economy 114, 5: 905-930.

Lanjouw, Peter, and Martin Ravallion. 1999. Benefit Incidence, Public Spending Reforms, and the Timing of Program Capture. World Bank Economic Review 13 (2): 257-73.

Lujala, Päivi, Jan Ketil Rød, and Nadia Thieme. 2007. Fighting over Oil: Introducing A New Dataset. Conflict Management and Peace Science 24, 3: 239-256.

Maizels, Alfred, and Machiko K. Nissanke. 1984. Motivations for Aid to Developing Countries. World Development 12, 9: 879-900.

McKinlay, Robert D., and Richard Little. 1977. A Foreign Policy Model of US Bilateral Aid Allocation. World Politics 30, 1: 58-86.

Michalopoulos, Stelios, and Elias Papaioannou. 2013. Pre-Colonial Ethnic Institutions and Contemporary African Development. Econometrica 81, 1: 113-152.

Michalopoulos, Stelios, and Elias Papaioannou. 2014. National Institutions and Subnational Development in Africa. Quarterly Journal of Economics 129, 1: 151-213.

Ministry of Commerce (MOFCOM). 2014. Measures for the Administration of Foreign Aid. 15 December 2014. Beijing: Ministry of Commerce. http://www.mof com.gov . $\mathrm{cn} /$ article/b/c/201411/20141100799438.shtml

Moser, Christine. 2008. Poverty Reduction, Patronage or Vote Buying? The Allocation of Public Goods and the 2001 Election in Madagascar. Economic Development and Cultural Change 57, 1: 137-162.

Moss, Todd, Gunilla Pettersson, and Nicolas van de Walle. 2007. An Aid-Institutions Paradox? A Review Essay on Aid Dependency and State Building in Sub-Saharan Africa, in: Reinventing Foreign Aid, edited by William Easterly, 255-281. Cambridge, UK: MIT Press.

Mthembu-Salter, Gregory. 2012. Goodwill and Hard Bargains: The DRC, China and India. South African Institute of International Affairs Occasional Paper 114. Johannesburg, South Africa: South African Institute of International Affairs.

$\mathrm{Mu}$, Ren and Xiaobo Zhang. 2014. Do Elected Leaders in a Limited Democracy Have Real Power? Evidence from Rural China. Journal of Development Economics 107, C: 1727.

Naím, Moisés. 2007. Rogue Aid. Foreign Policy. 14 February 2007.

National Geospatial-Intelligence Agency (NGA). 2011. World Port Index (Pub 150). Springfield, VA: National Geospatial-Intelligence Agency. Available at http://msi . nga.mil/NGAPortal.

National Oceanic and Atmospheric Administration (NOAA). 2014. Version 4 DMSPOLS Nighttime Lights Time Series. Boulder, CO: National Geophysical Data Center. Accessed 05 April 2014.

Nissanke, Machiko, and Marie Söderberg. 2014. The Changing Landscape in Aid Relationships in Africa: Can China's Engagement Make a Difference to African Development. Swedish Institute for International Affairs (SIIA) Working Paper. Stockholm, Sweden: SIIA. 
Nunnenkamp, Peter, Hannes Öhler, and Maximiliano Sosa Andrés. 2012. Need, Merit and Politics in Multilateral Aid Allocation: A District-Level Analysis of World Bank Projects in India. Kiel Working Paper No. 1783. Kiel, Germany: Kiel Institute for the World Economy.

OECD. 2005. Paris Declaration on Aid Effectiveness: Ownership, Harmonisation, Alignment, Results and Mutual Accountability. Paris, France: OECD Publications.

Öhler, Hannes, and Peter Nunnenkamp. 2014. Needs-based Targeting or Favoritism? The Regional Allocation of Multilateral Aid Within Recipient Countries. Kyklos 67, 3: 420-446.

Parks, Bradley C. 2014. Brokering Development Policy Change: The Parallel Pursuit of Millennium Challenge Account Resources and Reform. Ph.D. Dissertation. London, UK: London School of Economics and Political Science.

Powell, Joshua, and Michael G. Findley. 2012. The Swarm Principle? A Sub-national Spatial Analysis of Donor Coordination in Sub-Saharan Africa. Available at http://www . michael-findley.com/uploads/2/0/4/5/20455799/swarm_principle_coordination_ may2013.pdf.

Rajan, Raghuram G., and Arvind Subramanian. 2008. Aid and Growth: What Does the Cross-Country Evidence Really Show? Review of Economics and Statistics 90, 4: 643-665.

Rajkumar, Andrew S., and Vinaya Swaroop. 2008. Public Spending and Outcomes: Does Governance Matter? Journal of Development Economics 86: 96-111.

Ravallion, Martin. 2000. Monitoring Targeting Performance When Decentralized Allocations to the Poor Are Unobserved. World Bank Economic Review 14, 2: 331-45.

Ravallion, Martin. 2009. Are There Lessons for Africa from China's Success Against Poverty? World Development 37, 2: 303-313.

Reisen, Helmut, and Jean-Philippe Stijns 2011. Emerging Partners Create Policy Space for Africa. VoxEU.org. Available at http://www.voxeu.org/article/how-emerging-donors-are-creat (accessed 01 November 2014).

State Council. 2011. China's Foreign Aid. Beijing, China: Information Office of the State Council. 21 April 2011.

State Council. 2014. Full Text: China's Foreign Aid. Beijing, China: Information Office of the State Council. Available at http://news.xinhuanet.com/english/china/ 2014-07/10/c_133474011.htm (accessed 01 November 2014).

Strandow, Daniel, Michael Findley, Daniel Nielson, and Josh Powell. 2011. The UCDPAidData codebook on Geo-referencing Foreign Aid. Version 1.1. Uppsala Conflict Data Program. Uppsala, Sweden: Uppsala University.

Strange, Austin M., Bradley Parks, Michael J. Tierney, Andreas Fuchs, Axel Dreher, and Vijaya Ramachandran. 2013. China's Development Finance to Africa: A Media-Based Approach to Data Collection. CGD Working Paper 323. Washington, DC: Center for Global Development.

Strange, Austin M., Bradley Parks, Michael J. Tierney, Andreas Fuchs, and Axel Dreher. 2014a. Tracking Under-Reported Financial Flows: China's Development Finance and 
the Aid-Conflict Nexus Revisited. University of Heidelberg Discussion Paper 533. Heidelberg, Germany: Heidelberg University.

Strange, Austin M., Bradley Parks, Michael J. Tierney, Andreas Fuchs, and Axel Dreher. 2014b. Apples and Dragon Fruits: The Determinants of Aid and Other Forms of State Financing from China to Africa. Paper presented at the 2014 Annual Convention of the American Political Science Association.

Strange, Austin M., Brian ODonnell, Daniel Gamboa, Bradley Parks, and Charles Perla. 2014c. AidDatas Methodology for Tracking Under-Reported Financial Flows. Williamsburg, VA: AidData.

Tull, Denis M. 2006. China's Engagement in Africa: Scope, Significance and Consequences. Journal of Modern African Studies 44, 3: 459-479.

U.S. Geological Survey (USGS). 2005. Mineral Resources Data System: U.S. Geological Survey, Reston, VA.

van de Walle, Nicolas. 2007. Meet the New boss, Same as the Old Boss? The Evolution of Political Clientelism in Africa. In: Patrons, Clients, and Policies, edited by K. Herbert and I. W. Steven, 60-67. New York, NY: Cambridge University Press.

Weidmann, Nils B., Jan Ketil Rød, and Lars-Erik Cederman. 2010. Representing Ethnic Groups in Space: A New Dataset. Journal of Peace Research 47, 4: 491-499.

Werker, Eric D., Faisal Z. Ahmed, and Charles Cohen. 2009. How Is Foreign Aid Spent? Evidence from a Natural Experiment. American Economic Journal: Macroeconomics 1, 2: 225-244.

Werker, Eric D. 2012. The Political Economy of Bilateral Foreign Aid. In: Handbook of Safeguarding Global Financial Stability: Political, Social, Cultural, and Economic Theories and Models, edited by G. Caprio, 47-58. Academic Press.

Wright, Joseph. 2010. Aid Effectiveness and the Politics of Personalism. Comparative Political Studies 43, 6: 735-762.

Zhu, Xiao'ou. Forthcoming. Demystifying the Role of Chinese Commercial Actors in the Shaping China's Foreign Assistance: The Case of Post-war Sri Lanka. Stability: International Journal of Security and Development. 


\section{Figures and Tables}

Figure 1: Subnational Boundaries

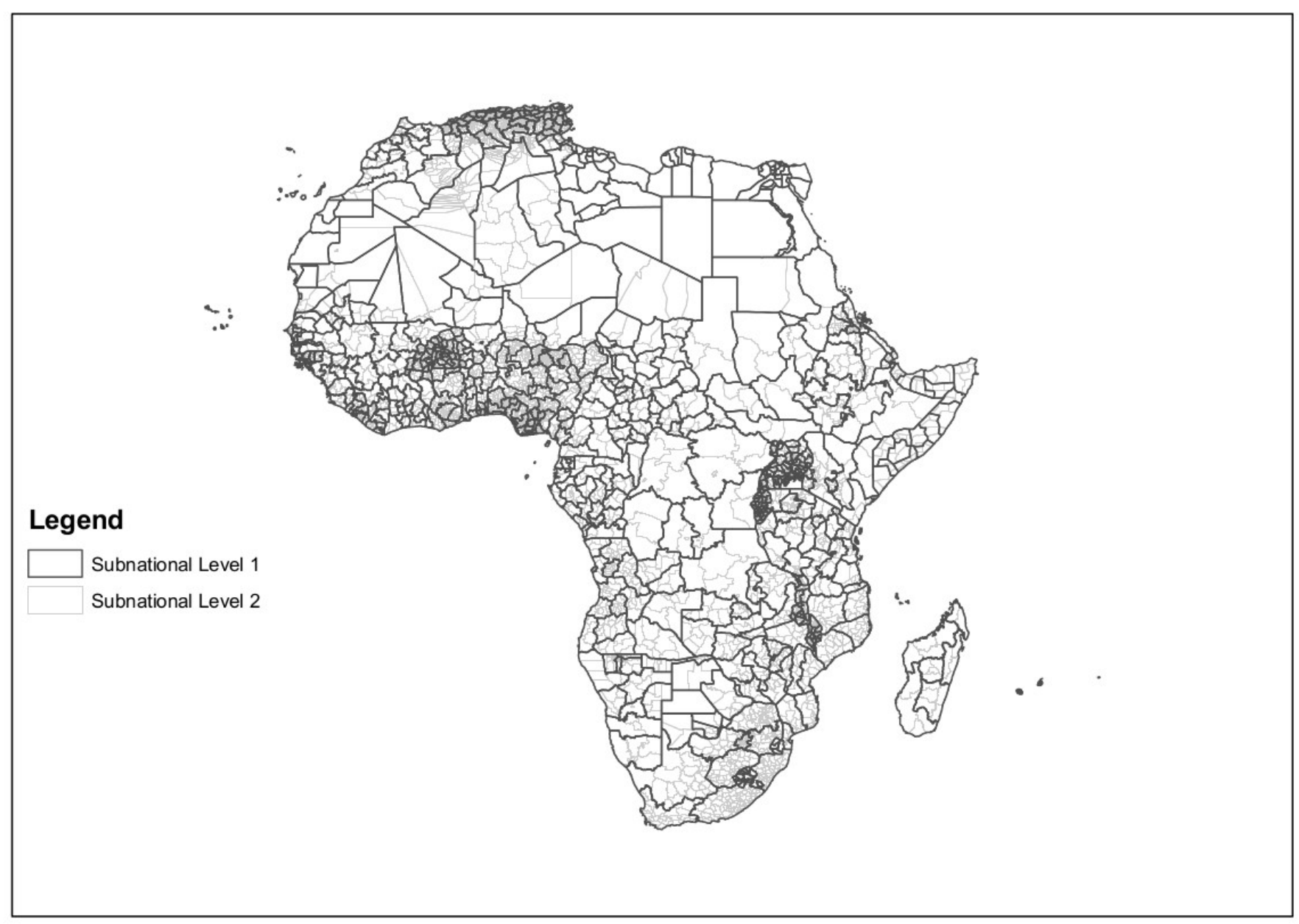


Figure 2: Value of Chinese Aid Projects per Subnational Unit in Africa (Total Value in million 2009 US\$, 2000-2011, ADM2)

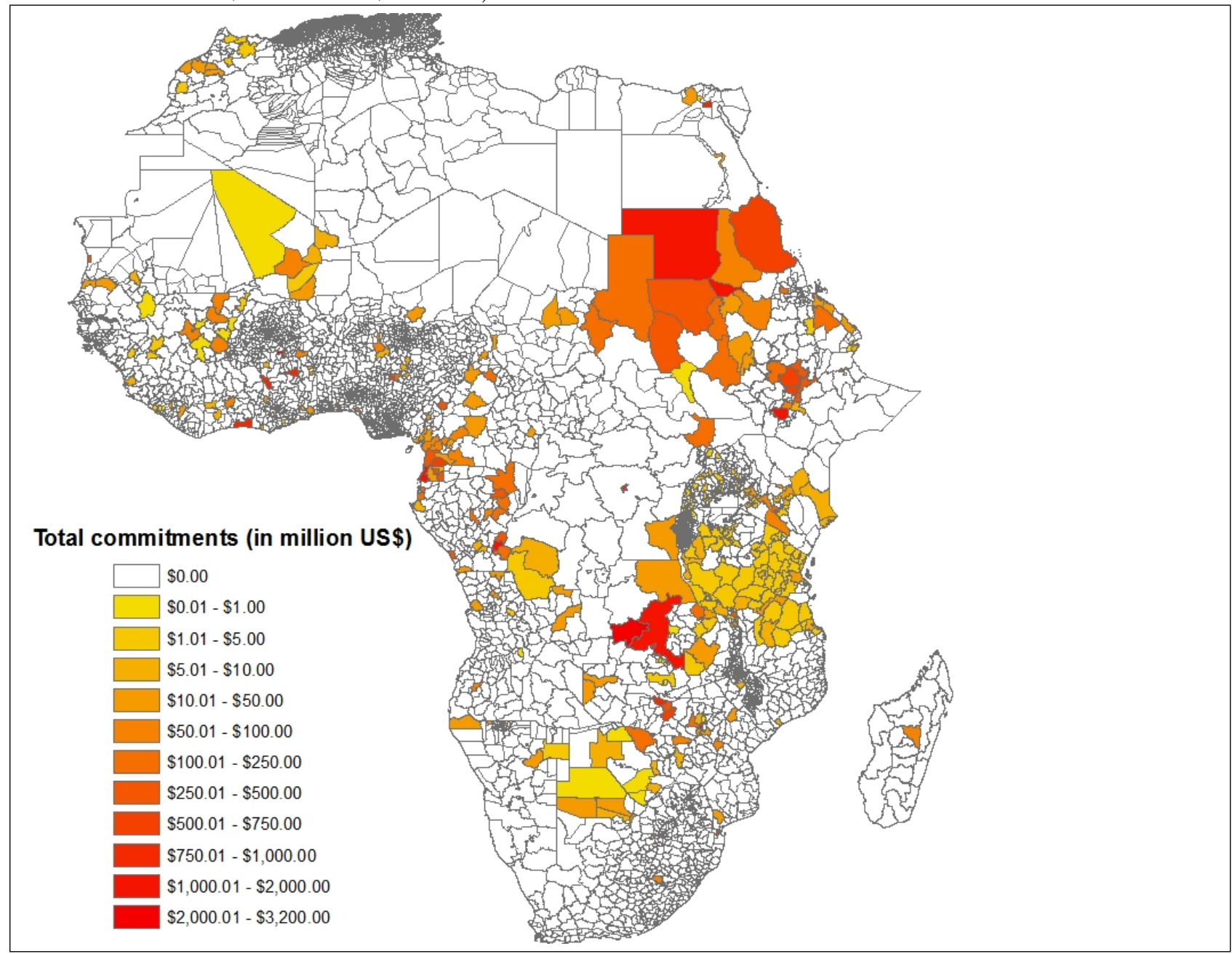


Figure 3: Chinese Aid Projects per Subnational Unit in Africa (Total Number of Projects, 2000-2011, ADM2)

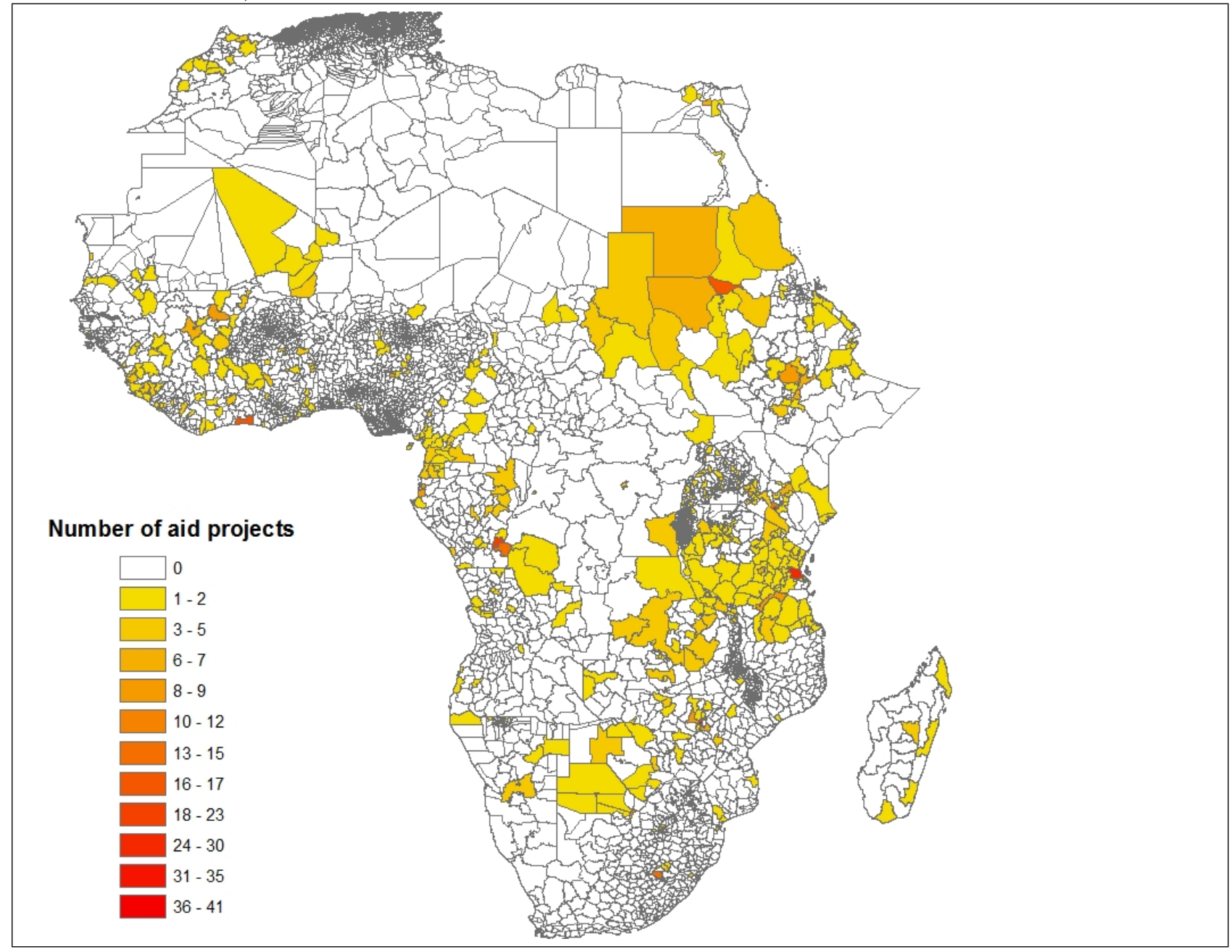


Figure 4: Birth regions of Effective Political Leaders in Africa (2000-2011, ADM2)

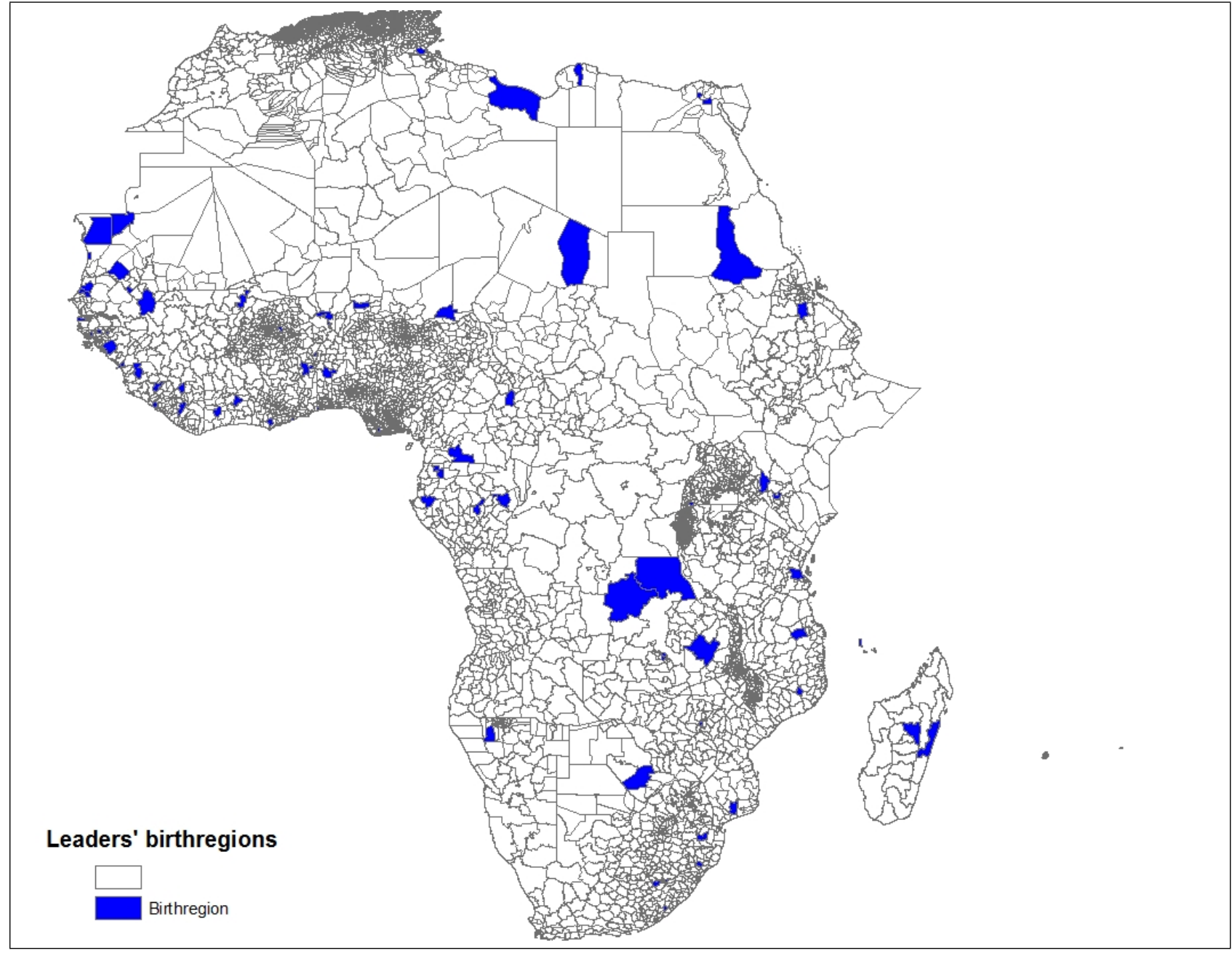




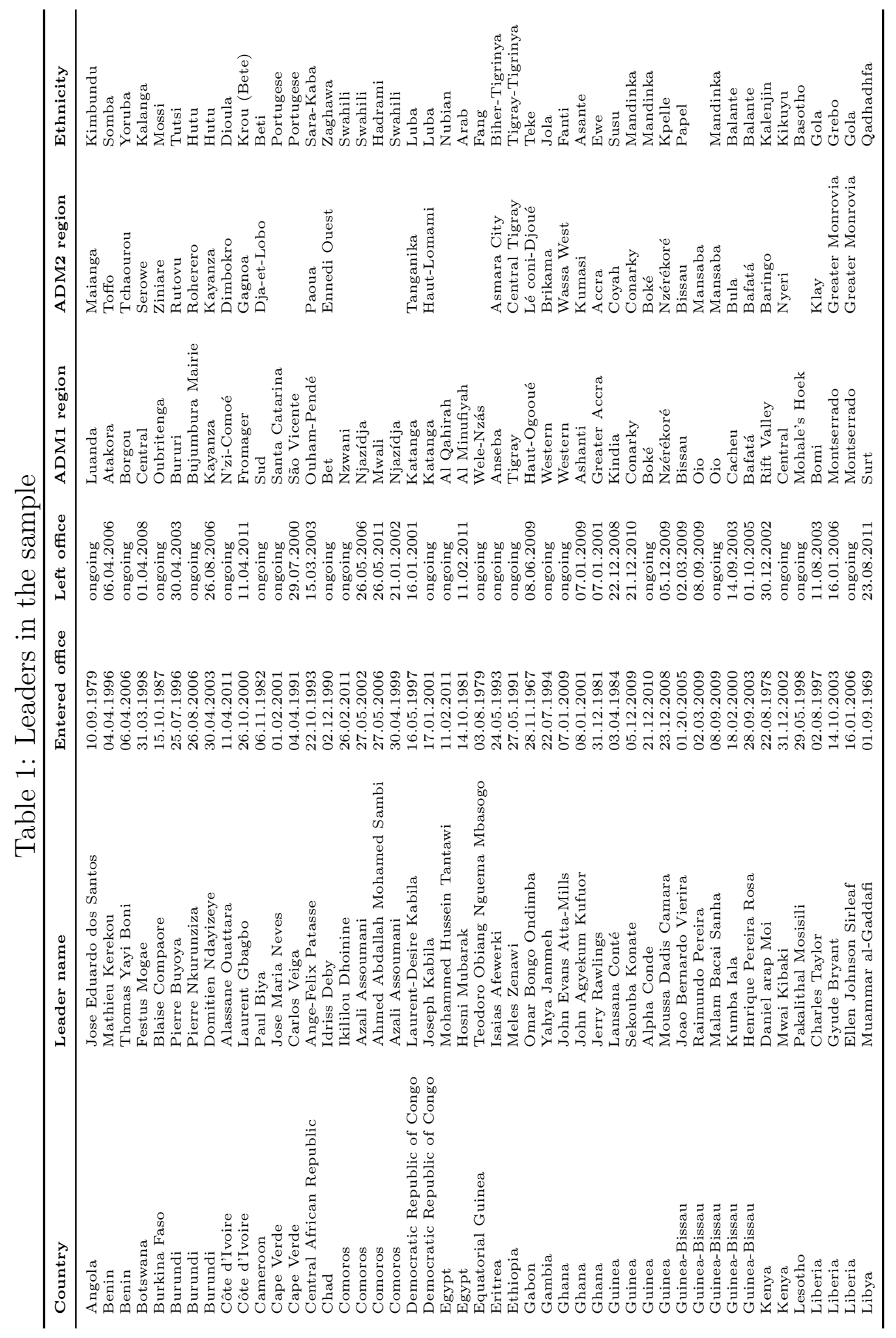




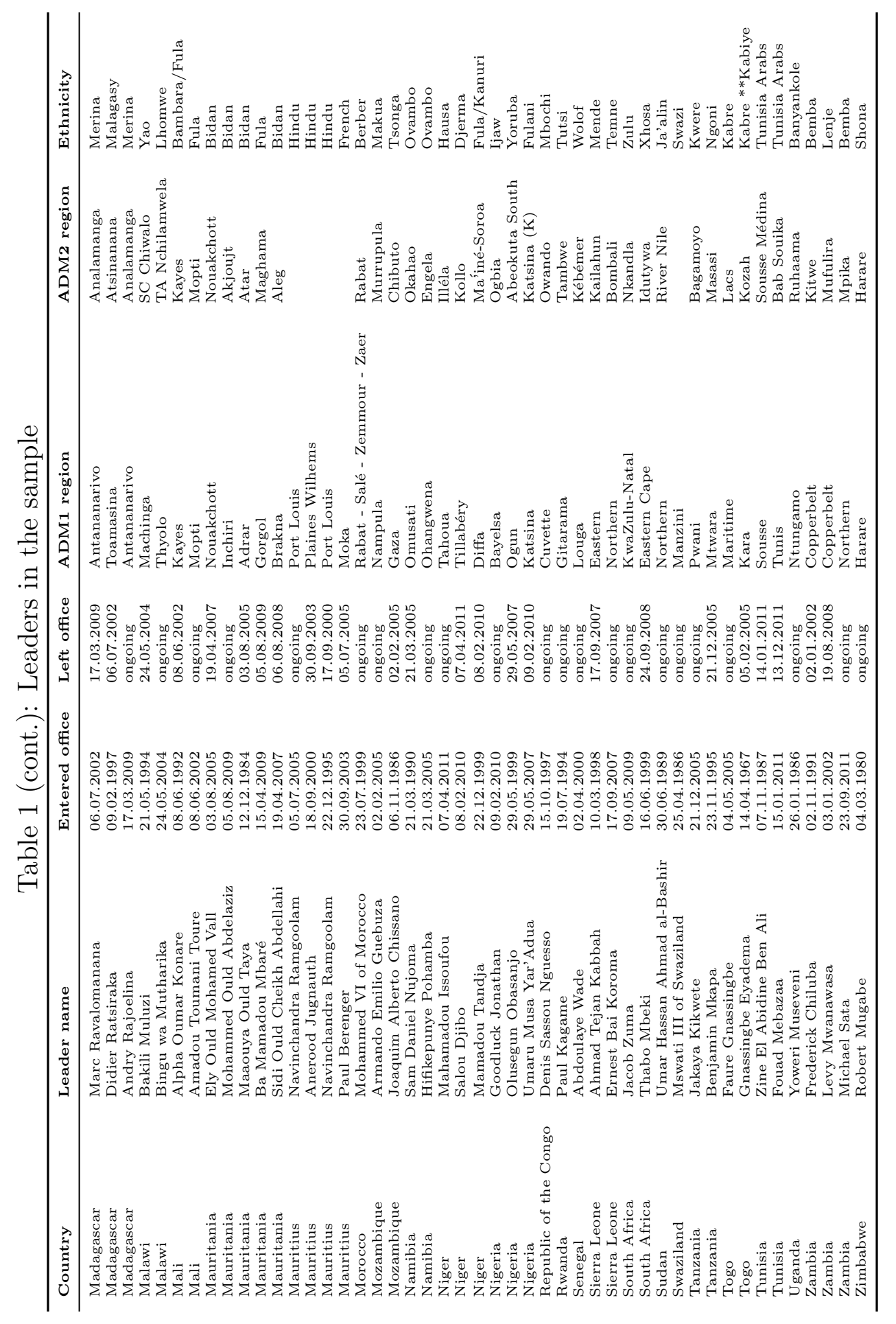


Table 2: Summary statistics, 2000-2011

\begin{tabular}{lccccc}
\hline Variable & Obs. & Mean & Std. Dev. & Min & Max \\
\hline Total flows (in levels) & 8,327 & $6.5 \mathrm{~m}$ & $86.8 \mathrm{~m}$ & 0 & $5.2 \mathrm{~b}$ \\
ODA-like flows (in levels) & 8,375 & $1.5 \mathrm{~m}$ & $29.1 \mathrm{~m}$ & 0 & $1.5 \mathrm{~b}$ \\
Project count (in levels) & 8,508 & 0.202 & 0.869 & 0 & 13 \\
Total World Bank commitments (in levels) & 8,508 & $5.86 \mathrm{~m}$ & $31.31 \mathrm{~m}$ & 0 & $2.06 \mathrm{~b}$ \\
Total IDA commitments (in levels) & 8,508 & $4.63 \mathrm{~m}$ & $16.39 \mathrm{~m}$ & 0 & $297 \mathrm{~m}$ \\
World Bank project count (in levels) & 8,508 & 1.10 & 3.279 & 0 & 82 \\
Birthregion & 8,508 & 0.067 & 0.249 & 0 & 1 \\
Light2000 (in levels) & 8,508 & 1.964 & 5.989 & 0 & 48.20 \\
Population2000 (in levels) & 8,508 & $1.1 \mathrm{~m}$ & $1.7 \mathrm{~m}$ & 6,047 & $21.9 \mathrm{~m}$ \\
Capitalregion & 8,508 & 0.066 & 0.249 & 0 & 1 \\
Mines (in levels) & 8,508 & 3.577 & 12.58 & 0 & 139 \\
Oilgas & 8,508 & 0.173 & 0.379 & 0 & 1 \\
Area (in levels) & 8,508 & 41,107 & 81,045 & 41.56 & $0.6 \mathrm{~m}$ \\
Ports & 8,508 & 0.186 & 0.389 & 0 & 1 \\
Roaddensity & 8,508 & 0.092 & 0.146 & 0 & 1.874 \\
\hline
\end{tabular}

Note: Summary statistics at the level of ADM1 regions. 
Table 3: Birth regions and Chinese aid, OLS, country-year fixed effects, 2000-2011

\begin{tabular}{|c|c|c|c|c|c|c|}
\hline & (1) & (2) & (3) & (4) & (5) & (6) \\
\hline Units of obs. & ADM1 & ADM2 & ADM1 & ADM2 & ADM1 & ADM2 \\
\hline $\begin{array}{l}\text { Dependent } \\
\text { variables }\end{array}$ & $\begin{array}{c}\text { Total } \\
\text { flows } \\
\text { (in logs) }\end{array}$ & $\begin{array}{c}\text { Total } \\
\text { flows } \\
\text { (in logs) }\end{array}$ & $\begin{array}{l}\text { ODA-like } \\
\text { flows } \\
\text { (in logs) }\end{array}$ & $\begin{array}{c}\text { ODA-like } \\
\text { flows } \\
\text { (in logs) }\end{array}$ & $\begin{array}{c}\text { Project } \\
\text { count } \\
\text { (in logs) }\end{array}$ & $\begin{array}{c}\text { Project } \\
\text { count } \\
\text { (in logs) }\end{array}$ \\
\hline Birthregion & $\begin{array}{c}0.688^{* *} \\
(0.323)\end{array}$ & $\begin{array}{l}0.554^{* *} \\
(0.252)\end{array}$ & $\begin{array}{c}0.283 \\
(0.206)\end{array}$ & $\begin{array}{l}0.392^{*} \\
(0.204)\end{array}$ & $\begin{array}{c}0.035 \\
(0.023)\end{array}$ & $\begin{array}{l}0.037^{*} \\
(0.022)\end{array}$ \\
\hline Light2000 & $\begin{array}{c}0.293^{* *} \\
(0.114)\end{array}$ & $\begin{array}{c}0.060^{* * *} \\
(0.018)\end{array}$ & $\begin{array}{c}0.242^{* *} \\
(0.120)\end{array}$ & $\begin{array}{c}0.038^{* *} \\
(0.015)\end{array}$ & $\begin{array}{c}0.024^{* * *} \\
(0.008)\end{array}$ & $\begin{array}{c}0.005^{* * *} \\
(0.001)\end{array}$ \\
\hline Popul & $\begin{array}{c}0.087 \\
(0.087)\end{array}$ & $\begin{array}{l}0.028^{*} \\
(0.014)\end{array}$ & $\begin{array}{c}0.014 \\
(0.073)\end{array}$ & $\begin{array}{c}0.008 \\
(0.009)\end{array}$ & $\begin{array}{l}0.012^{*} \\
(0.007)\end{array}$ & $\begin{array}{c}0.002^{* *} \\
(0.001)\end{array}$ \\
\hline Capitalregion & $\begin{array}{c}4.164^{* * * *} \\
(0.496)\end{array}$ & $\begin{array}{c}4.625^{* * *} \\
(0.527)\end{array}$ & $\begin{array}{c}2.837^{* * *} \\
(0.398)\end{array}$ & $\begin{array}{c}3.229^{* * * *} \\
(0.430)\end{array}$ & $\begin{array}{c}0.335^{* * *} \\
(0.038)\end{array}$ & $\begin{array}{c}0.355^{* * * *} \\
(0.042)\end{array}$ \\
\hline Min & $\begin{array}{l}0.117^{*} \\
(0.066)\end{array}$ & $\begin{array}{c}0.020 \\
(0.027)\end{array}$ & $\begin{array}{c}0.003 \\
(0.039)\end{array}$ & $\begin{array}{l}-0.001 \\
(0.013)\end{array}$ & $\begin{array}{c}0.007 \\
(0.005)\end{array}$ & $\begin{array}{c}0.001 \\
(0.002)\end{array}$ \\
\hline Oilgas & $\begin{array}{c}0.070 \\
(0.132)\end{array}$ & $\begin{array}{l}-0.053 \\
(0.036)\end{array}$ & $\begin{array}{c}0.077 \\
(0.122)\end{array}$ & $\begin{array}{l}-0.039 \\
(0.026)\end{array}$ & $\begin{array}{c}0.006 \\
(0.011)\end{array}$ & $\begin{array}{l}-0.004^{*} \\
(0.002)\end{array}$ \\
\hline Area & $\begin{array}{c}0.234^{* * * *} \\
(0.085)\end{array}$ & $\begin{array}{c}0.039^{* * *} \\
(0.013)\end{array}$ & $\begin{array}{c}0.183^{* *} \\
(0.077)\end{array}$ & $\begin{array}{c}0.023^{* *} \\
(0.009)\end{array}$ & $\begin{array}{c}0.022^{* * * *} \\
(0.007)\end{array}$ & $\begin{array}{c}0.003^{* * *} \\
(0.001)\end{array}$ \\
\hline Ports & $\begin{array}{l}-0.068 \\
(0.187)\end{array}$ & $\begin{array}{l}0.158^{*} \\
(0.087)\end{array}$ & $\begin{array}{l}-0.155 \\
(0.146)\end{array}$ & $\begin{array}{c}0.038 \\
(0.059)\end{array}$ & $\begin{array}{l}-0.013 \\
(0.013)\end{array}$ & $\begin{array}{l}0.012^{*} \\
(0.007)\end{array}$ \\
\hline Roaddensity & $\begin{array}{c}1.145 \\
(1.130)\end{array}$ & $\begin{array}{c}0.360 \\
(0.219)\end{array}$ & $\begin{array}{c}1.181 \\
(0.865)\end{array}$ & $\begin{array}{c}0.322^{* *} \\
(0.159)\end{array}$ & $\begin{array}{c}0.094 \\
(0.081)\end{array}$ & $\begin{array}{l}0.018^{*} \\
(0.010)\end{array}$ \\
\hline Cour & yes & yes & yes & yes & yes & yes \\
\hline & U.39 & & & 0.15 & 0.3 & 0.207 \\
\hline Obs & 8,327 & 69,0 & 8,375 & 69,115 & 8,508 & 69,252 \\
\hline Number of regic & 709 & 5,835 & 709 & 5,835 & 709 & 5,835 \\
\hline
\end{tabular}

Note: Standard errors (in parentheses) clustered at the leader level. 
Table 4: Birth regions and Chinese aid, OLS, country-year and region fixed effects, 20002011

\begin{tabular}{|c|c|c|c|c|c|c|}
\hline & (1) & $(2)$ & $(3)$ & (4) & $(5)$ & $(6)$ \\
\hline Units of obs. & ADM1 & ADM2 & ADM1 & ADM2 & ADM1 & ADM2 \\
\hline $\begin{array}{l}\text { Dependent } \\
\text { variables }\end{array}$ & $\begin{array}{c}\text { Total } \\
\text { flows } \\
\text { (in logs) }\end{array}$ & $\begin{array}{c}\text { Total } \\
\text { flows } \\
\text { (in logs) }\end{array}$ & $\begin{array}{c}\text { ODA-like } \\
\text { flows } \\
\text { (in logs) }\end{array}$ & $\begin{array}{l}\text { ODA-like } \\
\text { flows } \\
\text { (in logs) }\end{array}$ & $\begin{array}{c}\text { Project } \\
\text { count } \\
\text { (in logs) }\end{array}$ & $\begin{array}{c}\text { Project } \\
\text { count } \\
\text { (in logs) }\end{array}$ \\
\hline Birthregion & $\begin{array}{c}1.082^{* * *} \\
(0.369)\end{array}$ & $\begin{array}{c}0.277 \\
(0.257)\end{array}$ & $\begin{array}{l}0.569^{*} \\
(0.301)\end{array}$ & $\begin{array}{c}0.281 \\
(0.221)\end{array}$ & $\begin{array}{c}0.011 \\
(0.026)\end{array}$ & $\begin{array}{c}-0.012 \\
(0.020)\end{array}$ \\
\hline Country-year FE & yes & yes & yes & yes & yes & yes \\
\hline Region FE & yes & yes & yes & yes & yes & yes \\
\hline R-squared & 0.296 & 0.098 & 0.277 & 0.068 & 0.289 & 0.095 \\
\hline Observations & 8,327 & 69,817 & 8,375 & 69,880 & 8,508 & 70,020 \\
\hline Number of regions & 709 & 5,835 & 709 & 5,835 & 709 & 5,835 \\
\hline
\end{tabular}

Note: Standard errors (in parentheses) clustered at the leader level. 
Table 5: Birth regions and Chinese aid, OLS, country-year and region fixed effects, 20002011

\begin{tabular}{lcccccc}
\hline Units of obs. & $(1)$ & $(2)$ & $(3)$ & $(4)$ & $(5)$ & $(6)$ \\
Dependent & ADM1 & ADM2 & ADM1 & ADM2 & ADM1 & ADM2 \\
variables & Total & Total & ODA-like & ODA-like & Project & Project \\
& flows & flows & flows & flows & count & count \\
(in logs) & (in logs) & (in logs) & (in logs) & (in logs) & $($ in logs) \\
\hline Birthregion & $1.309^{* * *}$ & 0.330 & $0.593^{*}$ & 0.181 & 0.028 & -0.015 \\
& $(0.378)$ & $(0.254)$ & $(0.307)$ & $(0.224)$ & $(0.027)$ & $(0.022)$ \\
Prebirth & 0.467 & -0.088 & -0.772 & -0.589 & 0.058 & -0.029 \\
& $(0.893)$ & $(0.589)$ & $(0.562)$ & $(0.430)$ & $(0.071)$ & $(0.047)$ \\
Postbirth & $1.471^{*}$ & 0.527 & 0.836 & -0.294 & 0.083 & 0.001 \\
& $(0.816)$ & $(0.612)$ & $(0.731)$ & $(0.539)$ & $(0.059)$ & $(0.036)$ \\
\hline Country-year FE & yes & yes & yes & yes & yes & yes \\
Region FE & yes & yes & yes & yes & yes & yes \\
\hline R-squared & 0.297 & 0.098 & 0.278 & 0.069 & 0.290 & 0.095 \\
Observations & 8,327 & 69,817 & 8,375 & 69,880 & 8,508 & 70,020 \\
Number of regions & 709 & 5,835 & 709 & 5,835 & 709 & 5,835 \\
\hline
\end{tabular}

Note: Standard errors (in parentheses) clustered at the leader level. 
Table 6: Birth regions and World Bank aid, OLS, country-year fixed effects, 2000-2011

\begin{tabular}{|c|c|c|c|c|c|c|}
\hline \multirow[b]{2}{*}{ Units of obs. } & (1) & $(2)$ & $(3)$ & (4) & (5) & (6) \\
\hline & ADM1 & ADM2 & ADM1 & ADM2 & ADM1 & ADM2 \\
\hline \multirow{3}{*}{$\begin{array}{l}\text { Dependent } \\
\text { variables }\end{array}$} & Total & Total & IDA & IDA & Project & Project \\
\hline & flows & flows & flows & flows & count & count \\
\hline & $($ in $\log s)$ & (in logs) & $($ in $\log s)$ & $($ in $\log s)$ & $($ in $\log s)$ & (in logs) \\
\hline \multirow[t]{2}{*}{ Birthregion } & 0.090 & $0.682^{* *}$ & 0.110 & $0.684^{* *}$ & 0.086 & $0.053^{* *}$ \\
\hline & $(0.136)$ & $(0.317)$ & $(0.137)$ & $(0.294)$ & $(0.071)$ & $(0.025)$ \\
\hline \multirow[t]{2}{*}{ Light2000 } & $0.151^{* * *}$ & $0.225^{* * *}$ & $0.159^{* * *}$ & $0.222^{* * *}$ & $0.077^{* * *}$ & $0.013^{* * *}$ \\
\hline & $(0.037)$ & $(0.039)$ & $(0.037)$ & $(0.039)$ & $(0.024)$ & $(0.002)$ \\
\hline \multirow[t]{2}{*}{ Population2000 } & $0.393^{* * *}$ & $0.177^{* * *}$ & $0.342^{* *}$ & $0.161^{* * *}$ & $0.217^{* * *}$ & $0.013^{* * *}$ \\
\hline & $(0.133)$ & $(0.053)$ & $(0.139)$ & $(0.051)$ & $(0.075)$ & $(0.004)$ \\
\hline \multirow[t]{2}{*}{ Capitalregion } & 0.210 & $3.100^{* * *}$ & 0.128 & $2.968^{* * *}$ & 0.017 & $0.234^{* * *}$ \\
\hline & $(0.185)$ & $(0.548)$ & $(0.174)$ & $(0.548)$ & $(0.110)$ & $(0.042)$ \\
\hline \multirow[t]{2}{*}{ Mines } & $0.132^{* * *}$ & 0.082 & $0.105^{* *}$ & 0.057 & $0.079^{* * *}$ & 0.008 \\
\hline & $(0.048)$ & $(0.075)$ & $(0.051)$ & $(0.069)$ & $(0.025)$ & $(0.006)$ \\
\hline \multirow[t]{2}{*}{ Oilgas } & -0.133 & $-0.204^{*}$ & -0.108 & -0.181 & -0.078 & $-0.014^{* *}$ \\
\hline & $(0.121)$ & $(0.109)$ & $(0.118)$ & $(0.111)$ & $(0.061)$ & $(0.006)$ \\
\hline \multirow[t]{2}{*}{ Area } & $0.226^{* * *}$ & $0.186^{* * *}$ & $0.243^{* * *}$ & $0.186^{* * *}$ & $0.133^{* * *}$ & $0.013^{* * *}$ \\
\hline & $(0.059)$ & $(0.040)$ & $(0.058)$ & $(0.039)$ & $(0.035)$ & $(0.003)$ \\
\hline \multirow[t]{2}{*}{ Ports } & $0.209^{*}$ & $0.539^{* * *}$ & 0.188 & $0.461^{* *}$ & 0.076 & $0.038^{* * *}$ \\
\hline & $(0.111)$ & $(0.170)$ & $(0.114)$ & $(0.180)$ & $(0.054)$ & $(0.012)$ \\
\hline \multirow[t]{2}{*}{ Roaddensity } & 0.223 & 0.302 & 0.317 & 0.311 & 0.232 & $0.035^{*}$ \\
\hline & $(0.466)$ & $(0.222)$ & $(0.457)$ & $(0.226)$ & $(0.259)$ & $(0.019)$ \\
\hline Country-year FE & yes & yes & yes & yes & yes & yes \\
\hline R-squared & 0.518 & 0.330 & 0.539 & 0.343 & 0.585 & 0.357 \\
\hline Observations & 8,508 & 69,252 & 8,508 & 69,252 & 8,508 & 69,252 \\
\hline Number of regions & 709 & 5,835 & 709 & 5,835 & 709 & 5,835 \\
\hline
\end{tabular}

Note: Standard errors (in parentheses) clustered at the leader level. 
Table 7: Birth regions and World Bank aid, OLS, country-year and region-fixed effects, 2000-2011

\begin{tabular}{|c|c|c|c|c|c|c|}
\hline & (1) & $(2)$ & (3) & (4) & (5) & (6) \\
\hline Units of obs. & ADM1 & ADM2 & ADM1 & ADM2 & ADM1 & ADM2 \\
\hline \multirow{3}{*}{$\begin{array}{l}\text { Dependent } \\
\text { variables }\end{array}$} & Total & Total & IDA & IDA & Project & Project \\
\hline & flows & flows & flows & flows & count & count \\
\hline & (in $\log s)$ & $($ in $\log s)$ & $($ in $\log s)$ & (in logs) & $($ in $\log s)$ & $($ in $\log s)$ \\
\hline \multirow[t]{2}{*}{ Birthregion } & -0.127 & 0.114 & -0.061 & 0.169 & 0.060 & 0.015 \\
\hline & $(0.160)$ & $(0.387)$ & $(0.156)$ & $(0.384)$ & $(0.109)$ & $(0.027)$ \\
\hline \multirow{2}{*}{$\begin{array}{l}\text { Country-year FE } \\
\text { Region FE }\end{array}$} & yes & yes & yes & yes & yes & yes \\
\hline & yes & yes & yes & yes & yes & yes \\
\hline R-squared & 0.407 & 0.241 & 0.420 & 0.250 & 0.506 & 0.272 \\
\hline Observations & 8,508 & 70,020 & 8,508 & 70,020 & 8,508 & 70,020 \\
\hline Number of regions & 709 & 5,835 & 709 & 5,835 & 709 & 5,835 \\
\hline
\end{tabular}

Note: Standard errors (in parentheses) clustered at the leader level. 


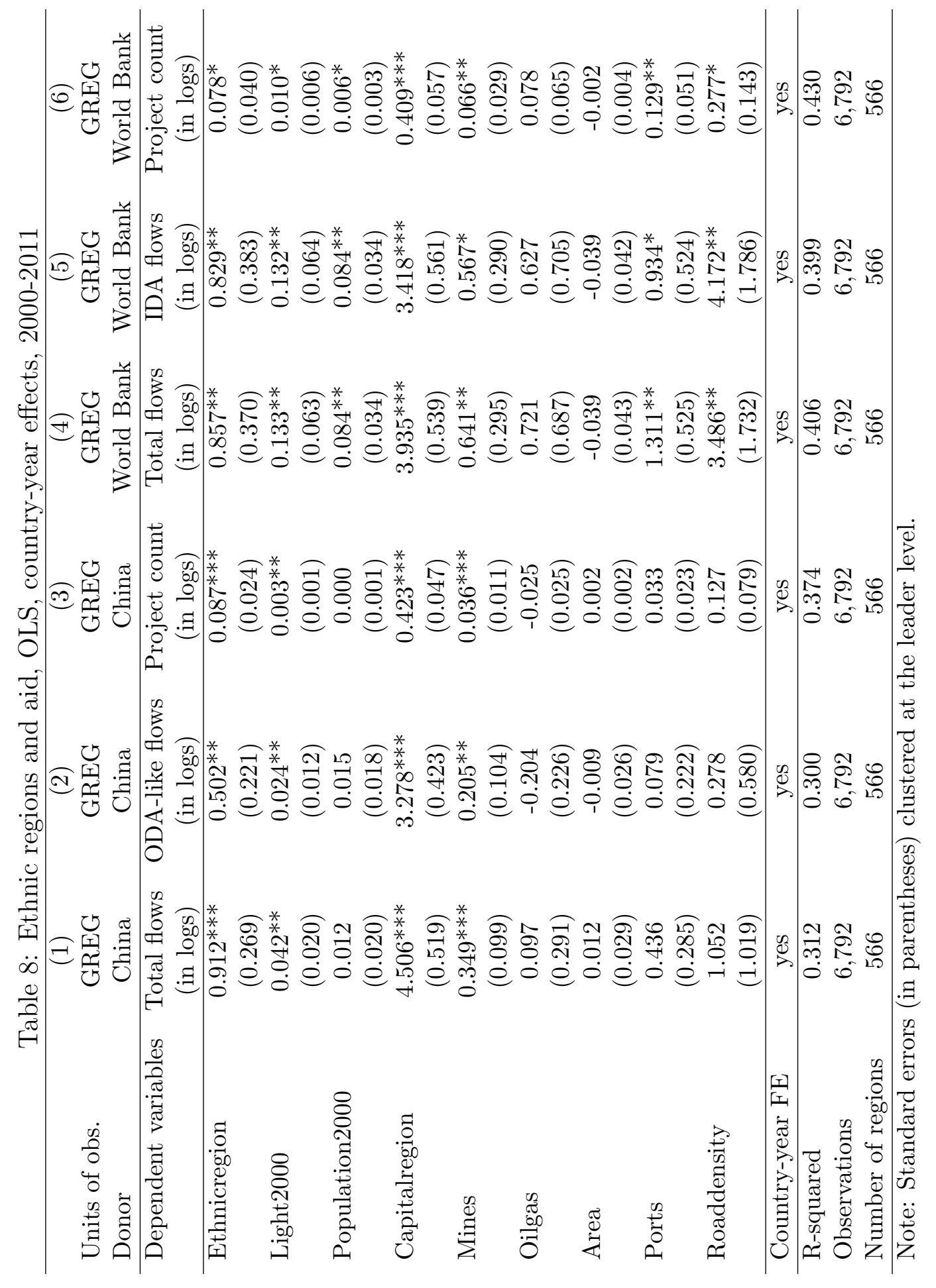




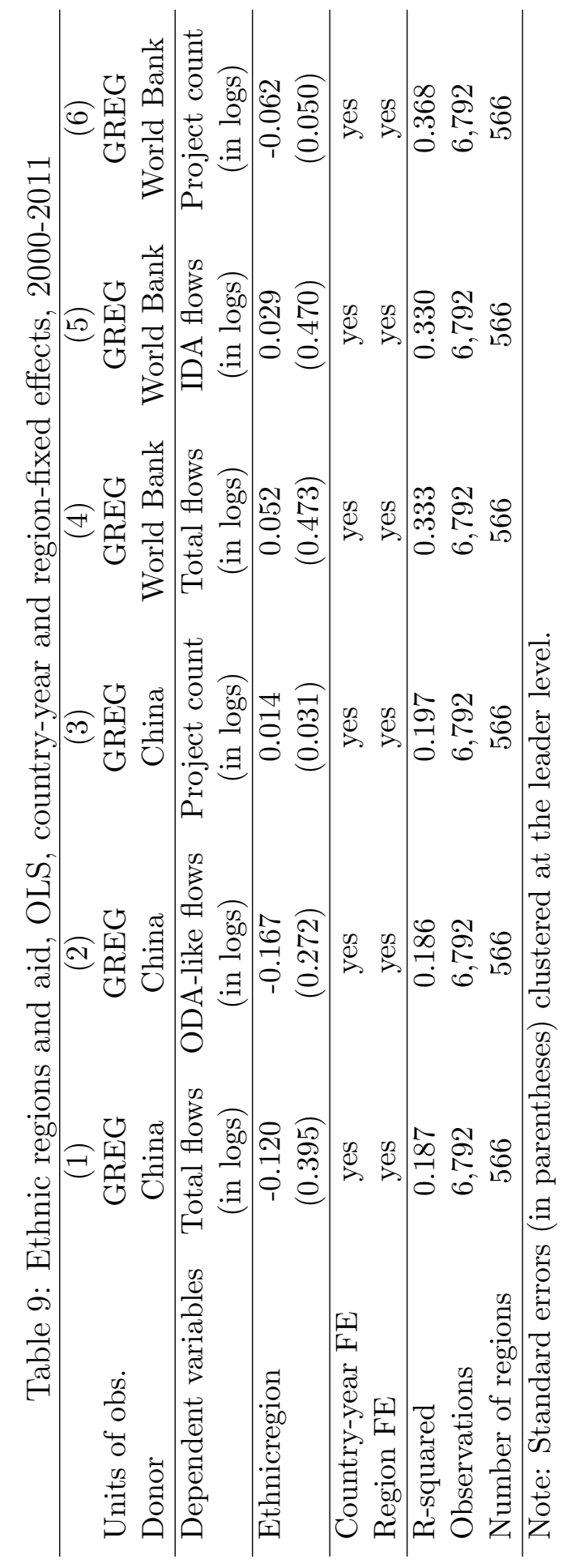

